\title{
Three New Genera and Six New Species of Lecanicephalideans (Cestoda) from Eagle Rays of the Genus Aetomylaeus (Myliobatiformes: Myliobatidae) from Northern Australia and Borneo
}

\author{
Author(s): K. R. Koch , K. Jensen, and J. N. Caira \\ Source: Journal of Parasitology, 98(1):175-198. 2012. \\ Published By: American Society of Parasitologists \\ DOI: http://dx.doi.org/10.1645/GE-2798.1 \\ URL: http://www.bioone.org/doi/full/10.1645/GE-2798.1
}

BioOne (www.bioone.org) is a nonprofit, online aggregation of core research in the biological, ecological, and environmental sciences. BioOne provides a sustainable online platform for over 170 journals and books published by nonprofit societies, associations, museums, institutions, and presses.

Your use of this PDF, the BioOne Web site, and all posted and associated content indicates your acceptance of BioOne's Terms of Use, available at www.bioone.org/page/terms_of_use.

Usage of BioOne content is strictly limited to personal, educational, and non-commercial use. Commercial inquiries or rights and permissions requests should be directed to the individual publisher as copyright holder. 


\title{
THREE NEW GENERA AND SIX NEW SPECIES OF LECANICEPHALIDEANS (CESTODA) FROM EAGLE RAYS OF THE GENUS AETOMYLAEUS (MYLIOBATIFORMES: MYLIOBATIDAE) FROM NORTHERN AUSTRALIA AND BORNEO
}

\author{
K. R. Koch, K. Jensen*, and J. N. Caira ${ }^{\star}$ \\ Department of Ecology and Evolutionary Biology and the Biodiversity Institute, University of Kansas, 1200 Sunnyside Ave., Lawrence, Kansas \\ 66045. e-mail: jensen@ku.edu
}

\begin{abstract}
New lecanicephalidean cestodes inhabiting the spiral intestine were investigated in 4 of the 6 known species of eagle rays of the genus Aetomylaeus Garman. Hosts examined consisted of 5 specimens of Aetomylaeus vespertilio from northern Australia, 5 of Aetomylaeus maculatus from Borneo, 10 of Aetomylaeus nichofii sensu stricto from Borneo, and 7 of Aetomylaeus cf. nichofii 2 from northern Australia. As a result of these new collections, 3 new genera and 6 new species of lecanicephalideans are formally described. Aetomylaeus vespertilio hosted the new genera and species Collicocephalus baggioi n. gen., n. sp. and Rexapex nanus $\mathrm{n}$. gen., n. sp., as well as Aberrapex weipaensis n. sp. Aetomylaeus maculatus and A. nichofii sensu stricto hosted 3 new species of the novel genus Elicilacunosus, with the former eagle ray hosting Elicilacunosus sarawakensis n. sp. and the latter hosting both Elicilacunosus dharmadii n. sp. and Elicilacunosus fahmii n. sp. No new lecanicephalideans were described from A. cf. nichofii 2. Collicocephalus n. gen. is conspicuously unique among the genera of its order in possessing a large, retractable apical organ that, in cross-section, is transversely oblong, rather than round. Rexapex $\mathrm{n}$. gen. is distinctive in its possession of an apical organ that bears 18 papilliform projections around its perimeter, and Elicilacunosus n. gen. is unlike any other known lecanicephalidean, or eucestode, in its possession of a region of musculo-glandular tissue along the midline of the dorsal and ventral surfaces of its proglottids, manifested externally as a tandem series of depressions. Among other features, A. weipaensis n. sp. differs from its congeners in its lack of post-ovarian vitelline follicles. All 6 new species were each restricted to a single species of Aetomylaeus. These records formally establish species of Aetomylaeus as hosts of lecanicephalideans. A summary of cestodes of myliobatid rays is presented.
\end{abstract}

The eagle rays, Myliobatidae Bonaparte, currently include a total of 25 species in the genera Aetobatus Blainville, Aetomylaeus Garman, Myliobatis Cuvier, and Pteromylaeus Garman (see Compagno, 2005; White et al., 2010; Naylor et al., 2012). Cestode data available to date for this family come primarily from species of Aetobatus and Myliobatis (see Table I; White et al., 2010) and include representatives of 5 cestode orders, with some emphasis on the Lecanicephalidea. Although no cestode data are available for either species of Pteromylaeus, cestode records exist for several species of Aetomylaeus (see Table I). However, these were generated prior to the realization that Aetomylaeus nichofii (Schneider) likely represents a complex of species (Last et al., 2010; Naylor et al., 2012). No cestodes have been reported from Aetomylaeus vespertilio (Bleeker), Aetomylaeus cf. nichofii 1 (sensu Naylor et al., 2012), or the poorly known Aetomylaeus milvus (Valenciennes in Müller and Henle), and many of the records from Aetomylaeus maculatus (Gray), Aetomylaeus nichofii, and Aetomylaeus cf. nichofii 2 (sensu Naylor et al., 2012) require confirmation. The present study aimed to expand knowledge of the cestode fauna of Aetomylaeus species, with particular emphasis on the lecanicephalideans.

In the most recent revision of the Lecanicephalidea, Jensen (2005) considered this order to consist of 72 species in 12 valid genera and noted that lecanicephalidean diversity was concentrated in rays of the Indo-Pacific region. Since then, 17 additional species of lecanicephalideans have been described (Wankhede, 2003; Pramanik and Manna, 2005; Jensen, 2006; Pramanik and Manna, 2006; Vankara et al., 2006; Pramanik and Manna, 2007; Vankara et al., 2007; Cielocha and Jensen, 2011; Jensen et al., 2011), all from Indo-Pacific rays. Moreover, 2 additional genera are now recognized in the order (Cielocha and Jensen, 2011;

Received 26 February 2011; revised 26 August 2011; accepted 1 September 2011.

* To whom correspondence should be addressed.

$\dagger$ Department of Ecology and Evolutionary Biology, University of Connecticut, Unit 3043, 75 North Eagleville Road, Storrs, Connecticut 06260-3043.

DOI: 10.1645/GE-2798.1
Jensen et al., 2011). The discovery of novel lecanicephalideans in the hosts examined here was thus anticipated given the strictly Indo-Pacific distribution of Aetomylaeus species.

Extensive fieldwork conducted over the last $10 \mathrm{yr}$ in northern Australia and throughout Malaysian and Indonesian Borneo resulted in the collection of cestodes from 4 of the 6 species of Aetomylaeus. These collections led to the discovery of multiple new cestode taxa, several of which are described below. Particular emphasis was placed on the erection of the new lecanicephalidean genera encountered in these hosts.

\section{MATERIALS AND METHODS}

To help with the validation of host identifications, all host individuals examined in this study were documented as follows. Each was assigned a unique host number and, for each animal, basic measurements and a series of photographs were taken. In addition, a small sample of liver tissue was removed and preserved in 95\% ethanol for molecular analysis. These data and images are accessible using the collection code and collection number for each host specimen (e.g., AU-43, CM03-61, etc.) at http://tapewormdb. uconn.edu/hosts.php. The unique host specimen number (collection code and collection number) is given below for each host individual following disc width.

The 5 specimens of $A$. vespertilio examined were collected either using gill nets or by a commercial trawling vessel. They consisted of 1 immature female (disk width [DW] $95 \mathrm{~cm}$; CM03-61) collected off Weipa (12 $40^{\prime} \mathrm{S}$, $141^{\circ} 52^{\prime} \mathrm{E}$ ), Queensland, Gulf of Carpentaria, in May 2004; 2 females (DW 148 and $150 \mathrm{~cm}$; AU-42 and AU-43, respectively) collected near Buffalo Creek $\left(12^{\circ} 20^{\prime} \mathrm{S}, 130^{\circ} 54^{\prime} \mathrm{E}\right)$, Darwin, Northern Territory, Timor Sea, in August 1997; 1 female (DW $86 \mathrm{~cm}$; NT-56) collected in the Arafura Sea east of the Wessel Islands $\left(11^{\circ} 17^{\prime} \mathrm{S}, 136^{\circ} 59^{\prime} \mathrm{E}\right)$ off the Northern Territory, in November 1999; and 1 specimen (sex and DW unknown; CMJ-7) collected off Cairns (16 $\left.52^{\prime} \mathrm{S}, 145^{\circ} 16^{\prime} \mathrm{E}\right)$, Queensland, Pacific Ocean, in July 2002.

The 5 specimens of $A$. maculatus examined were collected using trawling gear. The specimens from Malaysian Borneo consisted of 1 immature female (DW $43 \mathrm{~cm}$; BO-22) collected off Sematan $\left(01^{\circ} 48^{\prime} \mathrm{N}, 109^{\circ} 46^{\prime} \mathrm{E}\right)$, Sarawak, South China Sea, in June 2002 and 1 immature male (DW $29 \mathrm{~cm}$; BO-178) and 1 female (DW $36 \mathrm{~cm}$; BO-179) collected off Sematan $\left(01^{\circ} 48^{\prime} \mathrm{N}, 109^{\circ} 46^{\prime} \mathrm{E}\right)$, Sarawak, South China Sea, in May 2003. Specimens from Indonesian Borneo consisted of 1 immature male (DW $38 \mathrm{~cm}$; KA-53) collected off Kota Baru $\left(03^{\circ} 14^{\prime} \mathrm{S}, 116^{\circ} 13^{\prime} \mathrm{E}\right)$, South Kalimantan, Makassar Strait, in November 2006 and 1 female (DW $35 \mathrm{~cm}$; KA-104) 
TABle I. Cestode species reported from rays in the family Myliobatidae sensu Compagno (2005), White et al. (2010), and Naylor et al. (2012). Taxa described as part of this study are given in bold.

Host

Cestode Order: Species; Locality

Source

Aetobatus flagellum (Bloch and Schneider, 1801)

Lecanicephalidea: Polypocephalus bombayensis Shinde, Dhule, and Jadhav, 1991; India

Shinde et al. (1991)

Aetobatus guttatus (Shaw, 1804) (no records)

Aetobatus laticeps Gill, 1865*

Tetraphyllidea: Acanthobothrium monksi Marques, Brooks, and Barriga, 1997; Ecuador

Tetraphyllidea: Acanthobothrium nicoyaense Brooks and McCorquodale, 1995; Costa Rica

Marques et al. (1997)

Brooks and McCorquodale (1995)

Aetobatus ocellatus (Kuhl, 1823)*

Diphyllidea: Echinobothrium boisii Southwell, 1911; Sri Lanka

Lecanicephalidea: Adelobothrium aetiobatidis Shipley, 1900; New Caledonia

Lecanicephalidea: Calycobothrium typicum (Southwell, 1911) Stiles and Hassell, 1912; Sri Lanka

Lecanicephalidea: Cephalobothrium aetobatidis Shipley and Hornell, 1906; Sri Lanka

Lecanicephalidea: Hornellobothrium cobraformis Shipley and Hornell, 1906; Sri Lanka

Lecanicephalidea: Hornellobothrium extensivum Jensen, 2005; Australia

Lecanicephalidea: Hornellobothrium sp. A; Australia

Lecanicephalidea: Hornellobothrium sp. B; Australia

Lecanicephalidea: Kystocephalus translucens Shipley and Hornell, 1906; Sri Lanka

Lecanicephalidea: Staurobothrium aetobatidis Shipley and Hornell, 1905; Sri Lanka

Lecanicephalidea: Tenia narinari MacCallum, 1917; Indonesia

Lecanicephalidea: Tylocephalum aetiobatidis (Shipley and Hornell, 1905) Shipley and Hornell, 1906; Sri Lanka

Lecanicephalidea: Tylocephalum aurangabadensis Jadhav and Shinde, 1987; India

Lecanicephalidea: Tylocephalum girindrai Pramanik and Manna, 2007; India

Lecanicephalidea: Tylocephalum yorkei Southwell, 1925; India

Tetraphyllidea: Acanthobothrium aetiobatis (Shipley, 1900) Southwell, 1925; New Caledonia

Tetraphyllidea: Acanthobothrium arlenae Campbell and Beveridge, 2002; Australia

Tetraphyllidea: Acanthobothrium dysbiotos (MacCallum, 1921) Williams, 1969; Java

Tetraphyllidea: Myzocephalus narinari Shipley and Hornell, 1906; Sri Lanka

Tetraphyllidea: Myzophyllobothrium rubrum Shipley and Hornell, 1906; Sri Lanka, India

Trypanorhyncha: Didymorhynchus southwelli Beveridge and Campbell, 1988; Sri Lanka

Trypanorhyncha: Dollfusiella aetobati (Beveridge, 1990) Beveridge, Neifar, and Euzet, 2004; Australia

Trypanorhyncha: Kotorella pronosoma (Stossich, 1900) Euzet and Radujkovic, 1989; Indonesia

Trypanorhyncha: Oncomegas aetobatidis Campbell and Beveridge, 2009; Australia

Trypanorhyncha: Oncomegas australiensis Toth, Campbell and

Schmidt, 1992; Australia

Trypanorhyncha: Parachristianella baverstocki Beveridge, 1990; India

Trypanorhyncha: Proemotobothrium linstowi (Southwell, 1912) Beveridge and Campbell, 2001; Singapore

Trypanorhyncha: Shirleyrhynchus aetobatidis (Shipley and Hornell, 1906)

Beveridge and Campbell, 1988; Sri Lanka

Trypanorhyncha: Trygonicola macroporus (Shipley and Hornell, 1906)

Beveridge and Campbell, 1998; Malaysia

\section{Aetobatus narinari (Euphrasen, 1790)}

Lecanicephalidea: Tylocephalum? sp. (as Disculiceps sp.); Venezuela

Lecanicephalidea: Tylocephalum marsupium Linton, 1916; Dry Tortugas

Tetraphyllidea: Acanthobothrium colombianum Brooks and Mayes, 1980; Colombia

Tetraphyllidea: Acanthobothrium tortum (Linton, 1916) Baer and Euzet, 1962;

Dry Tortugas, Venezuela

Aetomylaeus maculatus (Gray, 1832)

Diphyllidea: Diagonobothrium assymetrum Shipley and Hornell, 1906; Sri Lanka

Lecanicephalidea: Elicilacunosus sarawakensis n. gen., n. sp.; Malaysia

Lecanicephalidea: Tylocephalum dierama Shipley and Hornell, 1906 species inquirendum; Sri Lanka

Lecanicephalidea: Discobothrium redacta nomen nudum; India

Lecanicephalidea: Discobothrium quadrisurculi nomen nudum; India

Southwell (1911)

Shipley (1900)

Southwell (1911)

Shipley and Hornell (1906)

Shipley and Hornell (1906)

Jensen (2005)

Butler (1987) (see Jensen, 2005)†

Butler (1987) (see Jensen, 2005)†

Shipley and Hornell (1906)

Shipley and Hornell (1905)

MacCallum (1917)

Shipley and Hornell (1905)

Jadhav and Shinde (1987)

Pramanik and Manna (2007)

Southwell (1925)

Shipley (1900)

Campbell and Beveridge (2002)

MacCallum (1921)

Shipley and Hornell (1906)

Shipley and Hornell (1906); Zaidi and Khan (1976)

Beveridge and Campbell (1988)

Beveridge (1990)

MacCallum (1917) (as Tetrarhynchus narinari; see Palm, 2004)

Campbell and Beveridge (2009)

Toth et al. (1992)

Palm (2004)

Palm (2004)

Shipley and Hornell (1906)

Beveridge and Campbell (1998)

Mayes and Brooks (1981)

Linton (1916)

Brooks and Mayes (1980)

Linton (1916); Mayes and Brooks (1981)

Shipley and Hornell (1906)

this study

Shipley and Hornell (1906):

Khambata and Bal (1953)

Khambata and Bal (1953) 
TABLE I. Continued.

Host

Cestode Order: Species; Locality

Source

Tetraphyllidea: Acanthobothrium myliomaculata Srivastav, Shweta and

Noopur, 1995; India

Tetraphyllidea: Anthobothrium panjadi (Shipley and Hornell, 1906) Shipley, 1909; Sri Lanka

Tetraphyllidea: Rhoptrobothrium myliobatidis Shipley and Hornell, 1906; Sri Lanka, Borneo

Aetomylaeus milvus (Valenciennes, in Muller and Henle, 1841) (no records)

Aetomylaeus nichofii (Bloch and Schneider, 1801)

Lecanicephalidea: Elicilacunosus dharmadii n. gen., n. sp.; Malaysia Lecanicephalidea: Elicilacunosus fahmii n. gen., n. sp.; Indonesia Tetraphyllidea: Acanthobothrium hanumantharaoi Rao, 1977; India Tetraphyllidea: Myliobatibothrium alii Shinde and Mohekar, 1983; India Tetraphyllidea: Myliobatibothrium singhi Sarwade, Shinde, Pawar, and Mahajan, 1995; India

Tetraphyllidea: Rhoptrobothrium chongi Jensen and Caira, 2006; Malaysia Tetraphyllidea: Rhoptrobothrium gambangi Jensen and Caira, 2006; Malaysia

Tetraphyllidea: Rhoptrobothrium limae Jensen and Caira, 2006; Malaysia

Aetomylaeus cf. nichofii 1 (no records)

Aetomylaeus cf. nichofii 2

Tetraphyllidea: Acanthobothrium rhynchobatidis Subhapradha, 1955; Australia

Aetomylaeus vespertilio (Bleeker, 1852)

Lecanicephalidea: Aberrapex weipaensis n. sp.; Australia

Lecanicephalidea: Collicocephalus baggio n. gen., n. sp.; Australia

Lecanicephalidea: Rexapex nanus n. gen., n. sp.; Australia

Myliobatis aquila (Linnaeus, 1758)

Diphyllidea: Echinobothrium mathiasi Euzet, 1951; France

Tetraphyllidea: Acanthobothrium batailloni Euzet, 1955; not given

Rhinebothriidea: Echeneibothrium myliobatis aquilae Diesing, 1863; not given

Rhinebothriidea: Rhinebothrium setiensis Euzet, 1955; not given

Rhinebothriidea: Rhodobothrium lubeti (Euzet, 1959) Campbell and Carvajal, 1979; France

Trypanorhyncha: Dollfusiella spinifer (Dollfus, 1969) Campbell and Beveridge, 1994; France

Trypanorhyncha: Parachristianella monomegacantha Kruse, 1959; France

Trypanorhyncha: Prochristianella glaber (Dollfus, 1969) Beveridge, 1990; France

Trypanorhyncha: Tetrarhynchobothrium setiense Dollfus, 1969; France

Trypanorhyncha: Tetrarhynchobothrium striatum (Wagener, 1854) Beveridge, 2008; Italy

Myliobatis australis Macleay, 1881

Tetraphyllidea: Acanthobothrium martini Campbell and Beveridge, 2002; Australia

Tetraphyllidea: Acanthobothrium pichelinae Campbell and Beveridge, 2002; Australia

Trypanorhyncha: Dollfusiella bareldsi (Beveridge, 1990) Beveridge, Neifar, and Euzet, 2004; Australia

Trypanorhyncha: Tetrarhynchobothrium australe Beveridge and Campbell, 1988; Australia

Trypanorhyncha: Trimacracanthus aetobatidis (Robinson, 1959) Beveridge and Campbell, 1987; Australia

\section{Myliobatis californica Gill, 1865}

Diphyllidea: Echinobothrium mexicanum Tyler and Caira, 1999; Mexico

Diphyllidea: Echinobothrium fautleyae Tyler and Caira, 1999; Mexico

Lecanicephalidea: Aberrapex senticosus Jensen, 2001; Mexico

Lecanicephalidea: Discobothrium myliobatidis Dailey and Mudry, 1968; California

Rhinebothriidea: Echeneibothrium opisthorchis (Riser, 1955) Yamaguti, 1959; California

Rhinebothriidea: Rhodobothrium brachyascum (Riser, 1955) Campbell and

Carvajal, 1979; California

Tetraphyllidea: Acanthobothrium holorhini Alexander, 1953; California

Tetraphyllidea: Acanthobothrium maculatum Riser, 1955; California

Tetraphyllidea: Acanthobothrium microcephalum Alexander, 1953; California
Srivastav et al. (1995):

Shipley (1909):

Shipley and Hornell (1906):; Jensen and Caira (2006)

this study

this study

Rao (1977)§

Shinde and Mohekar (1983)§

Sarwade et al. (1995)§

Jensen and Caira (2006)

Jensen and Caira (2006)

Jensen and Caira (2006)

Campbell and Beveridge (2002)

this study

this study

this study

Euzet (1951)\|

Euzet (1955)

Diesing (1863)

Euzet (1955)

Campbell and Carvajal (1979)

Beveridge et al. (2004)

Beveridge et al. (2004)

Dollfus (1969)

Dollfus (1969)

Beveridge (2008)

Campbell and Beveridge (2002)

Campbell and Beveridge (2002)

Beveridge (1990)

Beveridge and Campbell (1988)

Beveridge and Campbell (1987)

Tyler and Caira (1999)

Tyler and Caira (1999)

Jensen (2001)

Dailey and Mudry (1968)

Riser (1955)\#

Riser (1955)\#

Alexander (1953)\#

Riser (1955)\#

Alexander (1953)\# 
TABLE I. Continued.

Host

Cestode Order: Species; Locality Source

Tetraphyllidea: Acanthobothrium unilateralis Alexander, 1953; California

Tetraphyllidea: Caulobothrium tetrascaphium Riser, 1955; California

Trypanorhyncha: Mecistobothrium myliobati Heinz and Dailey, 1974; California

Myliobatis chilensis Philippi, 1892

Rhinebothriidea: Rhodobothrium mesodesmatum (Bahamonde and Lopez, 1962) Campbell and Carvajal, 1979; Chile

Tetraphyllidea: Acanthobothrium coquimbensis Carvajal and Jeges, 1980; Chile

Tetraphyllidea: Caulobothrium myliobatidis Carvajal, 1977; Chile

Myliobatis freminvillii Lesueur, 1824

Tetraphyllidea: Caulobothrium longicolle (Linton, 1890) Baer, 1948; Massachusetts

Myliobatis goodei Garman, 1885

Diphyllidea: Echinobothrium megacanthum Ivanov and Campbell, 1998; Argentina

Lecanicephalidea: Aberrapex arrhynchum (Brooks, Mayes, and Thorson, 1981) Jensen, 2001; Uruguay

Tetraphyllidea: Caulobothrium ostrowskiae Brooks, Mayes, and Thorson, 1981; Uruguay

Tetraphyllidea: Caulobothrium uruguayensis Brooks, Mayes, and Thorson, 1981; Uruguay

Tetraphyllidea: Phyllobothrium myliobatidis Brooks, Mayes, and Thorson, 1981; Uruguay

Myliobatis hamlyni Ogilby, 1911

Trypanorhyncha: Paroncomegas myliobatis Palm, 2004; Indonesia

Myliobatis longirostris Applegate and Fitch, 1964

Diphyllidea: Echinobothrium mexicanum Tyler and Caira, 1999; Mexico

Trypanorhyncha: Pseudochristianella nudiscula Campbell and Beveridge, 2006; Mexico

Myliobatis peruvianus Garman, 1913 (no records)

Myliobatis rhombus Basilewsky, 1855 (no records)

Myliobatis sp.

Lecanicephalidea: "Tylocephalum minutum Subhapradha, 1955"

Myliobatis tenuicaudatus Hector, 1877

Trypanorhyncha: Trimacracanthus aetobatidis (Robinson, 1959) Beveridge and Campbell, 1987; New Zealand

Myliobatis tobijei Bleeker, 1854

Tetraphyllidea: Caulobothrium tobejei (Yamaguti, 1934) Baer, 1948; Japan

Pteromylaeus asperrimus (Jordan and Evermann, 1898) (no records)

Pteromylaeus bovinus (Geoffrory St. Hilaire, 1817) (no records)

* Host given at Aetobatus narinari or Aetobatis [sic] narinari.

$\uparrow$ Host given as Hornellobothrium cobraformis.

+ Host given as Myliobatis maculata.

$\S$ Host given as Myliobatus nieullofii [sic]

\| Host given as Leiobatis aquila.

\# Host given as Aetobatus californicus or Holorhinus californicus.

- Host erroneously given as Myliobatis uruguayensis.

** Host given as "Mliobatis."

collected off Kalepseban $\left(03^{\circ} 14^{\prime} \mathrm{S}, 112^{\circ} 54^{\prime} \mathrm{E}\right)$, Central Kalimantan, Java Sea, in December 2006.

For clarity, specimens that appear to represent the original concept of $A$. nichofii as circumscribed by Naylor et al. (2012) have been referred to as $A$. nichofii sensu stricto; those belonging to what appear to be other members of this species complex have been given number designations, $A$. cf. nichofii 1 or $A$. cf. nichofii 2, per Naylor et al. (2012). All 17 specimens of the $A$. nichofii complex examined were collected using bottom trawls. The specimens of $A$. nichofii sensu stricto from Malaysian Borneo consisted of 3 females (DW 42, 50, and $35 \mathrm{~cm}$; BO-34, BO-37, and BO-59, respectively) collected off Mukah $\left(02^{\circ} 53^{\prime} \mathrm{N}, 112^{\circ} 05^{\prime} \mathrm{E}\right)$, Sarawak, South China Sea, in June 2002 and 1 immature male (DW $20 \mathrm{~cm}$; BO-145) and 1 female (DW $22 \mathrm{~cm}$; BO-180) collected off Sematan $\left(02^{\circ} 53^{\prime} \mathrm{N}, 112^{\circ} 05^{\prime} \mathrm{E}\right)$, Sarawak, South China Sea, in May 2003. The specimens of $A$. nichofii sensu stricto from Indonesian Borneo consisted of 1 female (DW $45 \mathrm{~cm}$; KA-21) and 1 male
(DW $45 \mathrm{~cm}$; KA-434) collected off Manggar $\left(01^{\circ} 12^{\prime} \mathrm{S}, 116^{\circ} 58^{\prime} \mathrm{E}\right)$, East Kalimantan, Makassar Strait, in November 2006 and August 2008, respectively; 1 immature male (DW $29 \mathrm{~cm}$; KA-90) collected off Muara Kintap $\left(03^{\circ} 54^{\prime} \mathrm{S}, 115^{\circ} 15^{\prime} \mathrm{E}\right)$, South Kalimantan, Makassar Strait, in November 2006; 1 female (DW $35 \mathrm{~cm}$; KA-96) collected off Takisung $\left(03^{\circ} 54^{\prime} \mathrm{N}, 114^{\circ} 36^{\prime} \mathrm{E}\right)$, South Kalimantan, Java Sea, in December 2006; and 1 female (DW $31 \mathrm{~cm}$; KA-362) collected off Sepuk Laut $\left(00^{\circ} 12^{\prime} \mathrm{S}, 109^{\circ} 05^{\prime} \mathrm{E}\right)$, West Kalimantan, South China Sea, in July 2008. The specimens of $A$. cf nichofii 2 from northern Australia consisted of 5 males (DW $33-53 \mathrm{~cm}$; NT50, NT-51, NT-57, NT-59, and NT-79) and 2 females (DW 58 and $44 \mathrm{~cm}$; NT-52 and NT-60, respectively) collected in the Arafura Sea east of the Wessel Islands $\left(11^{\circ} 17^{\prime} \mathrm{S}, 136^{\circ} 59^{\prime} \mathrm{E}\right)$, Northern Territory, in November 1999.

Necropsies were performed as follows. The body cavity of each host specimen was opened via a mid-ventral longitudinal incision, and the spiral intestine was removed and opened with a longitudinal incision. A 
subset of the worms found was fixed in $95 \%$ ethanol for future molecular analysis. The remaining worms were fixed in $10 \%$ formalin buffered with seawater and later transferred to $70 \%$ ethanol for storage. The spiral intestines and their remaining contents were fixed in $10 \%$ formalin buffered with seawater and then transferred to $70 \%$ ethanol for storage; they were subsequently examined for additional lecanicephalidean cestodes using a dissecting microscope. Cestode specimens were prepared as whole mounts as follows. They were hydrated in distilled water, stained with Delafield's hematoxylin, differentiated in tap water, destained in $70 \%$ acid ethanol, alkalinized in $70 \%$ basic ethanol, dehydrated in a graded ethanol series, cleared in methyl salicylate, and mounted on glass slides under coverslips in Canada balsam. Semi-permanent egg mounts were prepared as follows. A gravid proglottid was placed in lactophenol for $1 \mathrm{hr}$, transferred to a glass slide, broken open with insect pins, and mounted in lactophenol under a coverslip ringed with clear nail polish.

Specimens were prepared for examination using a scanning electron microscope (SEM) as follows. They were hydrated in a graded ethanol series, post-fixed in $1 \%$ osmium tetroxide overnight, washed in distilled water, dehydrated in a graded ethanol series, transferred to hexamethyldisilizane for $20 \mathrm{~min}$, air-dried, and mounted on aluminum stubs on double-sided adhesive carbon tape. Specimens were sputter coated with c. $30 \mathrm{~nm}$ of gold and examined with a Zeiss LEO 1550 field emission SEM at the Microscopy and Analytical Imaging Laboratory, University of Kansas, Lawrence, Kansas.

Selected whole worms, scolices, and proglottids were prepared as histological sections as follows. They were dehydrated in a graded ethanol series, cleared in xylene, and embedded in paraffin according to conventional techniques. Serial sections were cut at approximately $7 \mu \mathrm{m}$ intervals using a TBS Olympus Cut 4060 microtome, attached to glass slides by floating sections on $3 \%$ sodium silicate solution, and allowed to air dry. Sections were stained with Delafield's hematoxylin, counterstained with eosin, differentiated in Scott's solution, dehydrated in a graded ethanol series, transferred to xylene, and mounted in Canada balsam under coverslips.

Histological sections of selected proglottids were prepared as above and stained for glandular tissues using an adaptation of McManus' periodic acidSchiff (PAS) reaction (Sheehan and Hrapchak, 1987) according to the following procedure. Sections were placed in xylene, hydrated in a graded ethanol series, transferred to distilled water, immersed in $0.5 \%$ aqueous periodic acid for $5 \mathrm{~min}$, rinsed in several changes of distilled water, immersed in Schiff's reagent (Electron Microscopy Science, Hatfield, Pennsylvania) for $20 \mathrm{~min}$, rinsed in heated distilled water $(\sim 55 \mathrm{C})$ for $10 \mathrm{~min}$, washed in tap water for $10 \mathrm{~min}$, counterstained in Harris's hematoxylin, washed in tap water, dehydrated in a graded ethanol series, cleared in xylene, and mounted in Canada balsam under coverslips.

Line drawings were made using a drawing tube attached to a Zeiss Axioskop 2 Plus. Images of whole mounts and histological sections were taken using a Leica Firecam DFC 320 or DFC 480 attached to a Zeiss Axioskop 2. Measurements were made using a Leica Firecam DFC 320 digital camera mounted on a Zeiss Axioskop 2 Plus and the image analysis program Openlab Demo Version 4.0.4. Measurements are given in micrometers $(\mu \mathrm{m})$ unless otherwise indicated and are provided as the range followed in parentheses by the mean, standard deviation, number of worms examined, and the total number of measurements if more than 1 measurement was taken per worm. Measurements of reproductive organs are presented for mature proglottids only. Elasmobranch taxonomy follows Last and Stevens (2009) and Compagno (1999), as modified by Naylor et al. (2012). Microthrix terminology follows Chervy (2009).

Museum abbreviations are as follows: Institute of Parasitology (IPCAS), České Budějovice, Czech Republic (ASCR); Lawrence R. Penner Parasitology Collection, Department of Ecology and Evolutionary Biology, University of Connecticut, Storrs, Connecticut (LRP); Muzium Zoologi, Universiti Malaya, Kuala Lumpur, Malaysia (MZUM); Museum Zoologicum Bogoriense, Center for Biology, Indonesian Institute of Science, Cibinong, Jakarta-Bogor, Java, Indonesia (MZB); Queensland Museum, Queensland, Australia (QM); Sarawak Biodiversity Center, Kuching, Sarawak, Malaysia (SBC); United States National Parasite Collection, Beltsville, Maryland (USNPC).

\section{RESULTS}

\section{Collicocephalus n. gen.}

Diagnosis: Worms euapolytic. Scolex bearing 4 acetabula, apical modification of scolex proper, and apical organ. Acetabula in form of suckers. Apical modification of scolex proper with extensive aperture housing apical organ. Apical organ large, muscular, with glandular surface, retractable, in form of transverse oval pad when everted. Cephalic peduncle short or absent. Proglottids craspedote, with dorsal and ventral pair of lateral laciniations. Testes arranged in 2 columns, anterior to ovary, may be degenerated in terminal mature proglottid. External seminal vesicle saccate, extending from ootype to anterior margin of cirrus sac. Internal seminal vesicle absent. Cirrus sac round to pyriform. Cirrus unarmed. Ovary H-shaped in dorso-ventral view, tetralobed in cross-section. Vagina extending laterally in mature proglottid, along proglottid midline in posterior-most proglottids, from ootype to genital atrium, opening into genital atrium posterior to cirrus sac. Genital pores lateral, irregularly alternating. Uterus medial, saccate. Vitellaria follicular; follicles arranged in 4 columns, 1 dorsal and 1 ventral column on each lateral margin of proglottid, extending from anterior margin of ovary to near anterior margin of proglottid. Single pair of excretory ducts. Eggs unknown. In spiral intestine of Aetomylaeus (Myliobatidae), Northern Australia.

\section{Taxonomic summary}

Type and only species: Collicocephalus baggioi $\mathrm{n} . \mathrm{sp}$.

Etymology: Kollix, -ikos, Gr., roll or loaf of bread. This genus was named for the unusually oval shape of its apical organ which, when everted, resembles a loaf of bread.

\section{Remarks}

Its possession of a scolex consisting of 4 acetabula in the form of suckers and an apical organ, a vagina opening into the genital atrium posterior to the cirrus sac, and the presence of an extensive external seminal vesicle, clearly place Collicocephalus n. gen. in the order Lecanicephalidea. Collicocephalus n. gen. conspicuously differs from Paraberrapex Jensen, 2001, and Aberrapex Jensen, 2001 , in its possession of an apical organ. Its large, muscular, retractable apical organ clearly distinguishes it from Eniochobothrium Shipley and Hornell, 1906; Hornellobothrium Shipley and Hornell, 1906; Healyum Jensen, 2001; and Quadcuspibothrium Jensen, 2001, each of which possess a small, conical, glandular apical organ. Unlike Polypocephalus Braun, 1878, the apical organ of Collicocephalus $\mathrm{n}$. gen. is not divided into retractable tentacles. Whereas the testes in Collicocephalus n. gen. are arranged in 2 columns and the strobila is euapolytic, the testes in Anteropora Subhapradha, 1955, and Sesquipedalapex Jensen, Nikolov, and Caira, 2011, are arranged in a single column, and the strobila is hyperapolytic. Its craspedote and laciniate proglottids and saccate uterus distinguish Collicocephalus $\mathrm{n}$. gen. from Tetragonocephalum Shipley and Hornell, 1905, in which the proglottids are acraspedote and non-laciniate, the uterus has a conspicuous constriction at its mid-level, and the ovary is oval in dorso-ventral view. This new genus differs from Tylocephalum Linton, 1890, in bearing an apical organ that is oval in shape and retractable and vitelline follicles arranged in 1 dorsal and 1 ventral column on each lateral margin of the proglottid, rather than an apical organ that is round in shape and nonretractable and vitelline follicles that are circumcortical or arranged in more than 2 columns on each lateral margin. Collicocephalus $\mathrm{n}$. gen. differs from Hexacanalis Perrenoud, 1931, in its possession of a single pair, rather than 3 pairs, of excretory ducts. Its ovary, which is 
tetralobed in cross-section, distinguishes Collicocephalus n. gen. from Corrugatocephalum Caira, Jensen, and Yamane, 1997, in which the ovary is trilobed in cross-section. Collicocephalus n. gen. is most similar to Lecanicephalum Linton, 1890. It can, however, be distinguished from the latter genus in that its proglottids are craspedote and laciniate, rather than only weakly craspedote and non-laciniate, as well as in its lack of postovarian vitellaria. Furthermore, whereas the apical organ of Collicocephalus n. gen. is in the form of a thick pad, that of Lecanicephalum is in the form of a sheet. Finally, the distinctive circular muscle bundles seen in the apical organ of Lecanicephalum are absent in Collicocephalus n. gen.

\section{Collicocephalus baggioi $\mathrm{n}$. sp.}

(Figs. 1-16)

Description (based on 27 specimens: 16 whole mounts of mature worms, frontal sections of 2 scoleces with apical organ everted, frontal sections of 2 scoleces with apical organ retracted, crosssections of 1 mature proglottid, and 6 scoleces and 1 whole worm prepared for SEM): Worms 2.1-5.1 mm (3.1 \pm 0.9 ; 16) long; maximum width at scolex, euapolytic; proglottids 20-71 (39 \pm 16 ; $16)$ in number. Scolex 129-203 (161 $\pm 24 ; 11)$ long by 218-350 (291 $\pm 34 ; 14)$ wide, consisting of 4 acetabula, apical modification of scolex proper and apical organ. Acetabula in form of suckers, 54-82 (64 $\pm 7 ; 13 ; 26)$ long by $56-74(65 \pm 5 ; 13 ; 26)$ wide. Apical modification of scolex proper with extensive aperture at center housing apical organ. Apical organ retractable (Fig. 6), large, muscular, with glandular surface, in form of transverse oval pad when everted (Figs. 5, 16).

Acetabular rims with trullate spinitriches and capilliform filitriches (Figs. 9, 10). Distal acetabular surface and scolex proper with capilliform filitriches (Fig. 12). Apical organ with papilliform filitriches (Fig. 7). Proglottids with acicular filitriches (Fig. 13).

Cephalic peduncle short or absent. Proglottids craspedote, with dorsal and ventral pair of lateral laciniations; laciniations inconspicuous in mature proglottids. Immature proglottids 18 $69(37 \pm 16 ; 16)$ in number, initially wider than long, becoming longer than wide with maturity; posterior-most immature proglottid $236-554(375 \pm 77 ; 16)$ long by $122-312(216 \pm 53$; 16) wide. Mature proglottids $1-3$ in number, 770-1,103 (945 \pm 85 ; 16) long by $146-282(216 \pm 38 ; 16)$ wide. Testes $19-29(23 \pm 3 ; 14)$ in number, $18-74(42 \pm 14 ; 15 ; 45)$ long by $27-109(67 \pm 18 ; 15$; 45 ) wide, extending from anterior margin of proglottid to ovary, slightly overlapping anterior margin of ovary, 2 columns in dorsoventral view (Fig. 1), 1 row deep in cross-section, may be degenerated in terminal mature proglottid; post-ovarian testes absent. Vasa efferentia not observed. Vas deferens extending laterally in proglottid from ootype to anterior margin of cirrus sac, enlarged to form external seminal vesicle in terminal mature proglottids in which testes are degenerated. External seminal vesicle extensive, saccate, extending laterally in proglottid from ootype to anterior margin of cirrus sac. Internal seminal vesicle absent. Cirrus sac round to pyriform, slightly angled anteriorly, 87-170 (127 $\pm 20 ; 16)$ long by 67-165 (106 $\pm 24 ; 16)$ wide, containing coiled cirrus. Cirrus microtriches absent. Ovary $\mathrm{H}-$ shaped in dorso-ventral view, tetralobed in cross-section (Fig. 15), 223-351 (299 $\pm 40 ; 15)$ long by 108-434 (169 $\pm 76 ; 15)$ wide, lobulated, symmetrical; ovarian bridge at middle of ovary.

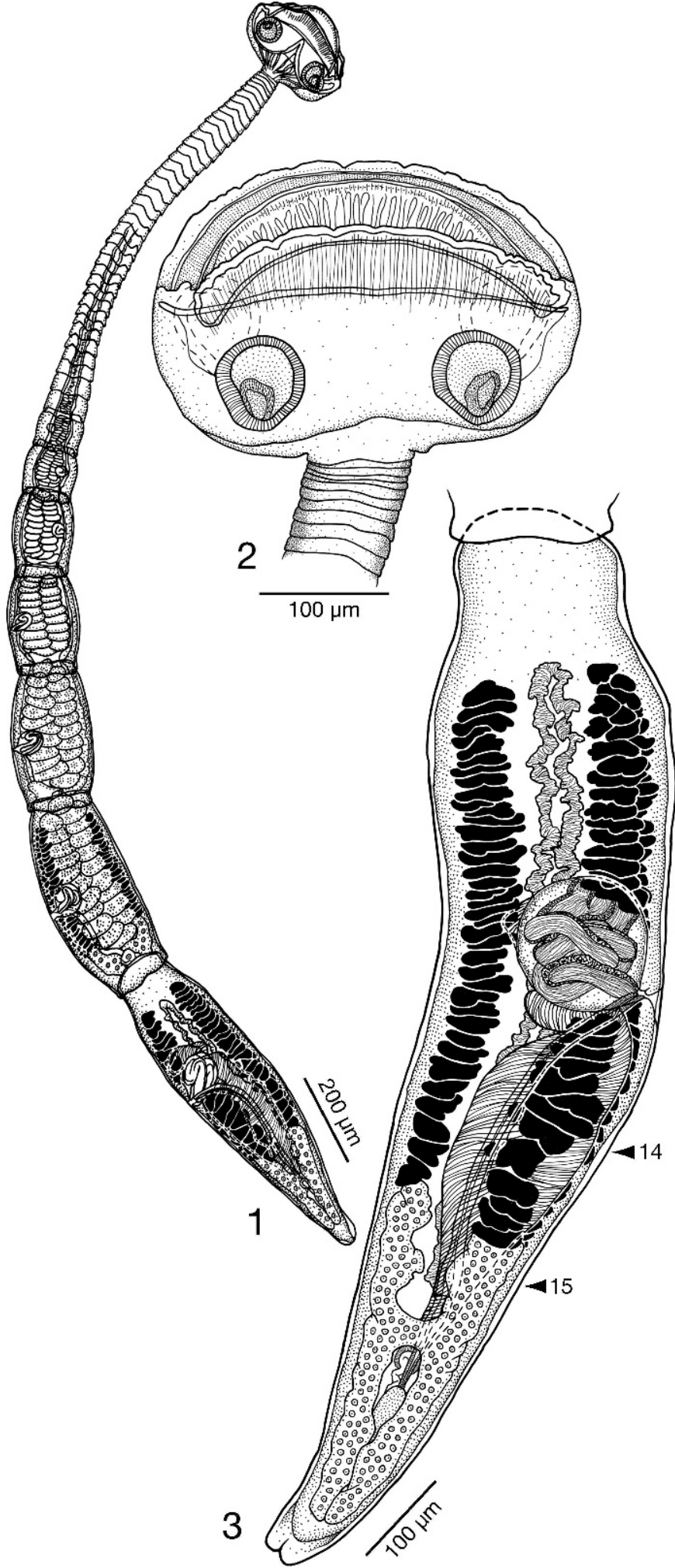

FiguRes 1-3. Line drawings of Collicocephalus baggioi n. gen., n. sp. (1) Whole worm. (2) Scolex. (3) Mature terminal proglottid. Arrows indicate level of cross-sections in Figures 14 and 15. 


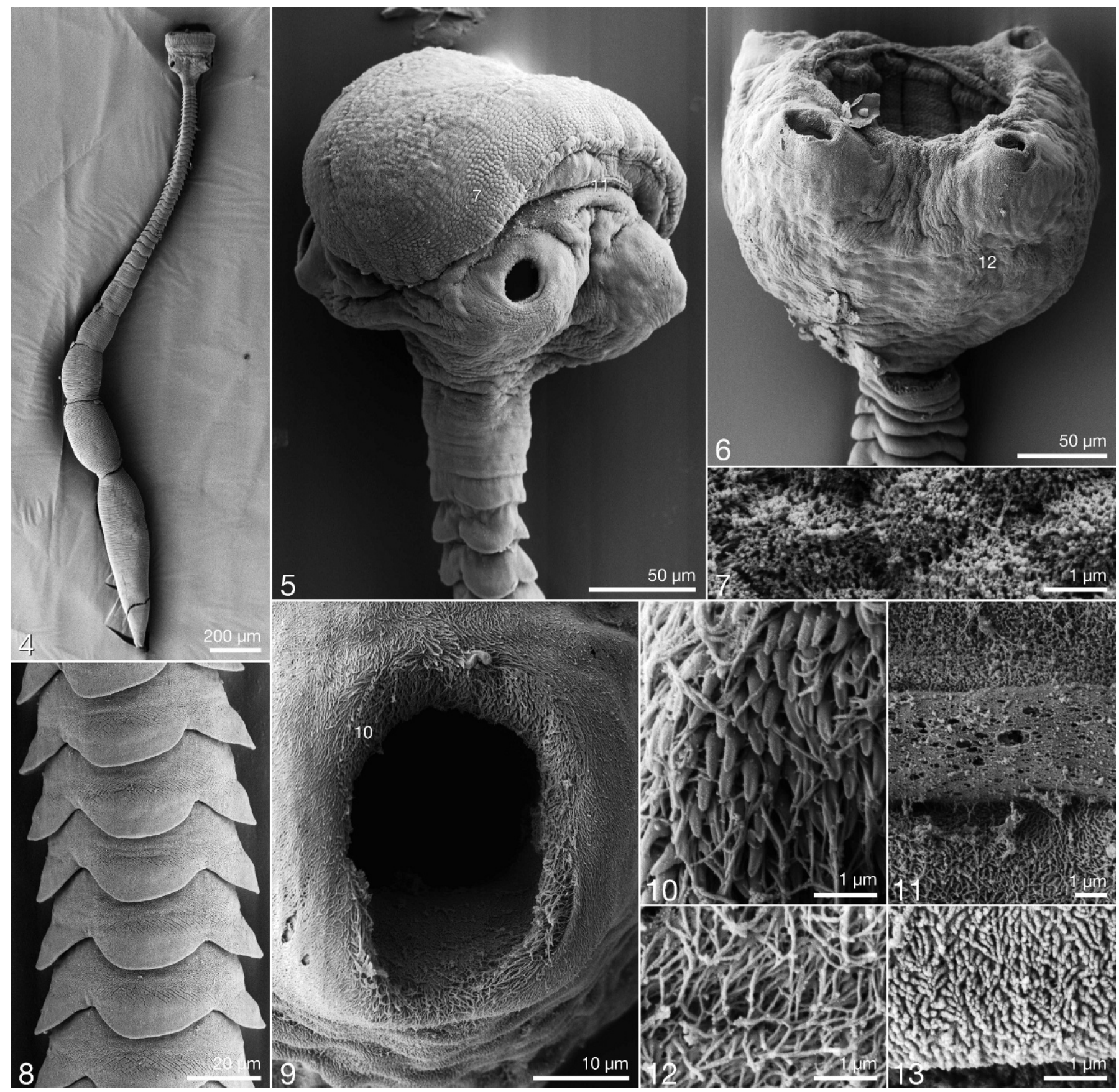

FIgURES 4-13. Scanning electron micrographs of Collicocephalus baggioi n. gen., n. sp. (4) Whole worm with apical organ fully everted. (5) Scolex with apical organ everted. Small numbers indicate location of detail in Figures 7 and 11. (6) Scolex with apical organ retracted. Small number indicates location of detail in Figure 12. (7) Apical organ with papilliform filitriches. (8) Enlarged view of laciniate proglottids. (9) Enlarged view of acetabulum. Small number indicates location of detail in Figure 10. (10) Acetabular rim with trullate spinitriches and capilliform filitriches. (11) Enlarged view of apical modification of scolex proper with acicular and capilliform filitriches and region devoid of microtriches. (12) Scolex proper with capilliform filitriches. (13) Posterior margin of anterior proglottid with acicular filitriches.

Mehlis' gland near posterior margin of ovary. Vagina extending laterally in mature proglottids, medially in terminal mature proglottids in which testes are degenerated, from ootype to genital atrium, opening into genital atrium posterior to cirrus sac. Genital pores lateral, irregularly alternating, $56-70 \%(61 \pm 4 ; 16)$ of proglottid length from posterior end. Uterus saccate, extending medially in proglottid from ovarian bridge to level of anterior- most vitelline follicles. Vitellaria follicular, medullary; follicles arranged in 4 columns, 1 dorsal and 1 ventral column on each lateral margin of proglottid in cross-section (Fig. 14), extending from anterior margin of ovary to near anterior margin of proglottid, may overlap ovary, $10-38(23 \pm 7 ; 16 ; 48)$ long by 14-68 (40 $\pm 14 ; 16$; 48) wide. Single pair of excretory ducts (Fig. 15). Eggs not observed. 

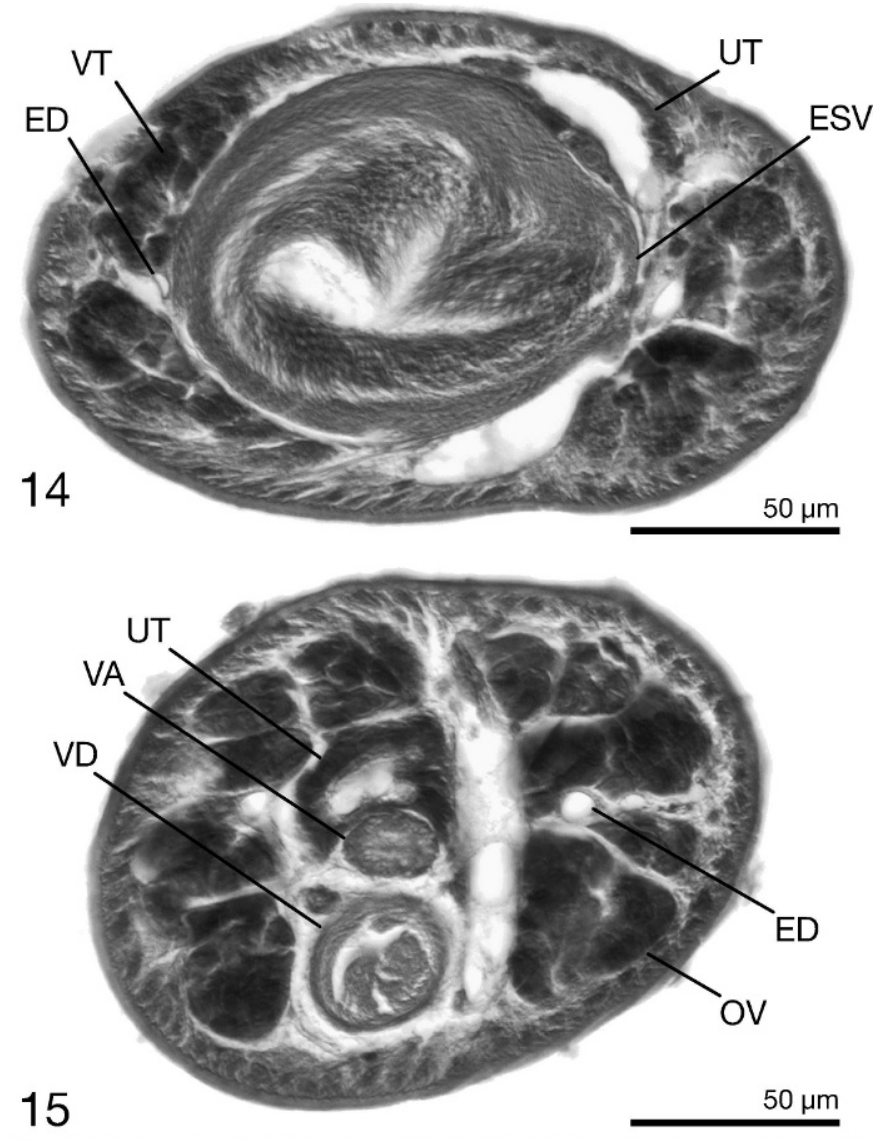

15

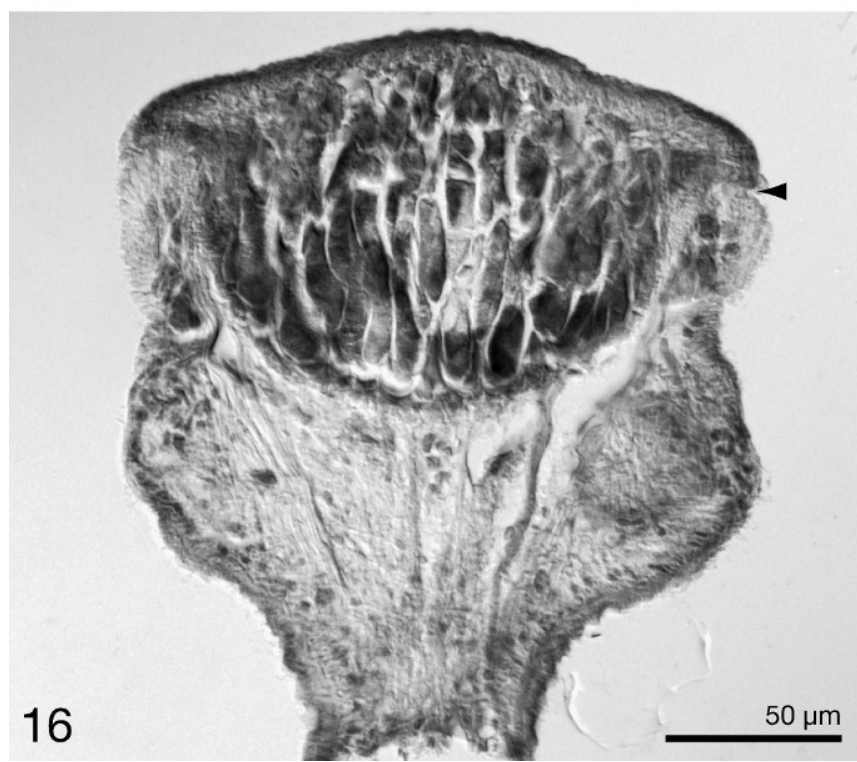

Figures 14-16. Collicocephalus baggioi n. gen., n. sp. (14) Crosssection through mature proglottid at level of external seminal vesicle. (15) Cross-section through mature proglottid at level of tetralobed ovary anterior to ovarian bridge. (16) Frontal section through scolex. Arrow indicates boundary between apical modificaton of scolex proper and apical organ. Abbreviations: ED, excretory duct; ESV, external seminal vesicle; OV, ovary; UT, uterus; VA, vagina; VD, vas deferens; VT, vitelline follicle.

\section{Taxonomic summary}

Type and only host: Aetomylaeus vespertilio (Bleeker) (CM0361), the ornate eagle ray (Myliobatiformes: Myliobatidae).

Site of infection: Spiral intestine.

Type locality: Off Weipa $\left(12^{\circ} 40^{\prime} \mathrm{S}, 141^{\circ} 52^{\prime} \mathrm{E}\right)$, Queensland, Australia, Gulf of Carpentaria.

Type specimens: Holotype (QM No. G233499), 7 paratypes (5 whole mounts, frontal sections of 1 scolex with apical organ everted, and 1 scolex with apical organ retracted; QM Nos. G233500-G233508); 6 paratypes (USNPC No. 104892); 6 paratypes (4 whole mounts, frontal sections of scolex with apical organ everted and cross-sections of mature proglottid of 1 specimen, and 1 scolex with apical organ retracted; LRP Nos. 7701-7711). Whole worm and 6 scoleces prepared for SEM (and their stobilar vouchers) retained in the personal collection of $\mathrm{K}$. Jensen at the University of Kansas.

Prevalence: One of 5 host individuals examined (20\%).

Etymology: This species is named for Julian Baggio, of Cairns Marine, Australia, for his assistance with the collection of host specimens from Weipa, Australia.

\section{Remarks}

This species, currently the only member of its genus, has an unusually wide range in total length as compared with the other lecanicephalidean species described in this study. Of the 16 whole worm paratypes included in this description, 10 were of the larger type and 6 were of the smaller type. This relatively large range in total length appears to be mainly the result of variation in the numbers of immature and mature proglottids, with smaller worms having only 1 or 2 mature proglottids, while larger worms have up to 3 mature proglottids. These differences were, however, considered to be well within the range of intraspecific variation.

\section{Elicilacunosus n. gen.}

Diagnosis: Worms euapolytic. Scolex bearing 4 acetabula, apical modification of scolex proper, and apical organ. Acetabula in form of suckers. Apical modification of scolex proper oval to elongate, cylindrical, partially invaginable, with aperture, housing apical organ. Apical organ oblong, primarily glandular, retractable. Cephalic peduncle present or absent. Proglottids craspedote, non-laciniate; posterior immature and mature proglottids with region of musculo-glandular tissue along midline of dorsal and ventral surfaces manifested externally as tandem series of depressions. Testes arranged in 2 regular columns, anterior to ovary. Vas deferens extending laterally in proglottid from ootype to cirrus sac, not expanded to form external seminal vesicle. Internal seminal vesicle not observed. Cirrus sac pyriform. Cirrus unarmed. Ovary essentially Hshaped in dorso-ventral view, bilobed in cross-section. Vagina extending laterally in proglottid from ootype to genital atrium, opening into genital atrium posterior to cirrus sac. Genital pores lateral, irregularly alternating. Uterus saccate, submedial. Vitellaria follicular, medullary; follicles arranged in 4 columns, 1 column dorsal and 1 ventral to testes (never lateral to testes), anterior to ovary. Single pair of excretory ducts. Eggs oval, with bipolar filaments. In spiral intestine of Aetomylaeus (Myliobatidae), South China Sea. 


\section{Taxonomic summary}

Type species: Elicilacunosus sarawakensis n. sp.

Additional species: Elicilacunosus dharmadii n. sp.; Elicilacunosus fahmii n. sp.

Etymology: Elix, -icis, L., trench; lacuna, L., cavity, hollow. This genus is named for the unique region of musculo-glandular tissue along the midline of the dorsal and ventral surfaces of the proglottids, which is manifested externally as tandem series of depressions.

\section{Remarks}

Among elasmobranch tapeworms, its possession of a scolex bearing 4 acetabula and an apical organ, as well as a vagina opening into the genital atrium posterior to the cirrus sac, clearly places Elicilacunosus n. gen. in the Lecanicephalidea. Elicilacunosus n. gen. is morphologically very much unlike any of the genera previously described in the order. It differs conspicuously from the 15 genera of Lecanicephalidea now recognized in its possession of a region of musculo-glandular tissue along the midline of the dorsal and ventral surfaces of the proglottid, manifested externally as a tandem series of depressions. It further differs from all 15 genera in that the vitelline follicles are dorsal and ventral, rather than lateral, to each column of testes. This new genus can be further distinguished from Aberrapex, Anteropora, Hornellobothrium, Paraberrapex, and Quadcuspibothrium in its possession of acetabula in the form of suckers, rather than bothridia. Elicilacunosus n. gen. further differs from Sesquipedalapex in being euapolytic rather than hyperapolytic. Its possession of a single pair of excretory ducts further distinguishes it from Lecanicephalum, Polypocephalus, Tetragonocephalum, and Tylocephalum, each with 2 pairs of excretory ducts, and from Hexacanalis, which possesses 3 pairs of excretory ducts. Whereas Corrugatocephalum and Healyum each possess a total of only 3 testes, Elicilacunosus n. gen. possesses many testes arranged in 2 distinct lateral columns. The anterior immature proglottids of Elicilacunosus n. gen. are not laterally expanded as in Eniochobothrium and Hornellobothrium. Furthermore, whereas the apical organ of Elicilacunosus n. gen. is elongate and retractable, it consists of multiple tentacles in Polypocephalus and an oval pad in Collicocephalus.

The function of the unusual column of regular depressions consisting of patches of musculo-glandular tissue along the midline of the dorsal and ventral surfaces of the proglottids of Elicilacunosus n. gen. remains a puzzle. This feature is unique among the over 80 described species of lecanicephalideans; in fact, to our knowledge, this feature is unique among tapeworms in general. Only in the proteocephalidean Ophiotaenia gallardi (Johnston, 1911) Freze, 1965 , has a superficially similar arrangement of depressions or pores been described. In their redescription of $O$. gallardi, de Chambrier and de Chambrier (2010) presented figures (their figs. 3, 4) depicting a series of "uterine pore-like structures" (de Chambrier and de Chambrier, 2010) arranged in tandem on the ventral surface of a subset of terminal gravid proglottids. However, it was clearly demonstrated by these authors that these "pore-like structures" are definitively associated with the uterus (see de Chambrier and de Chambrier, 2010; their fig. 11). The enigmatic surface modification in Elicilacunosus n. gen. species appears to involve both the tegument and parenchyma. However, the depressions exhibit no apparent connection to the reproductive or excretory systems. Given its musculo-glandular nature, the tissues associated with these depressions may aid in the attachment of these small worms to the intestinal mucosa of their hosts. The results of PAS staining of this region in cross-section of proglottids of E. fahmii n. sp. is described below. Clearly, this hypothesis requires further investigation.

\section{Elicilacunosus sarawakensis $\mathbf{n}$. sp.}

(Figs. 17-20, 24-30)

Description (based on 10 specimens: 8 whole mounts of mature worms and 2 whole worms prepared for SEM): Worms 890-1,830 $(1,175 \pm 354 ; 7)$ long; maximum width at terminal proglottid, euapolytic; proglottids $18-24(22 \pm 2 ; 8)$ in number. Scolex 43-74 $(53 \pm 11 ; 7)$ long by $50-63(55 \pm 4 ; 7)$ wide, consisting of 4 acetabula, apical modificaton of scolex proper, and apical organ. Acetabula in form of suckers, $26-33(30 \pm 2 ; 7 ; 14)$ long by $22-31$ $(27 \pm 3 ; 7 ; 12)$ wide. Apical modification of scolex proper elongate, cylindrical (Fig. 19), partially invaginable (Fig. 18), with aperture, housing apical organ. Apical organ primarily glandular, retractable, 17-38 (23 \pm 7 ; 6) long by 30-38 (35 $\pm 3 ; 7)$ wide (in retracted and everted state).

Anterior and lateral acetabular rims with coniform spinitriches and capilliform filitriches (Figs. 26, 27); posterior acetabular rims with capilliform filitriches only (Fig. 26). Scolex proper with papilliform filitriches (Fig. 29). Proglottids with small scolopate spinitriches, becoming shorter and more conical toward posterior margin of proglottid (Fig. 30).

Cephalic peduncle absent. Proglottids craspedote, non-laciniate; posterior immature and mature proglottids with region of musculo-glandular tissue along midline of dorsal and ventral surfaces manifested externally as tandem series of depressions (Figs. 24, 28). Immature proglottids 17-23 (21 \pm 2 ; 8) in number, initially wider than long, becoming longer than wide with maturity; posterior-most immature proglottid 138-390 (210 \pm $89 ; 8)$ long by $80-190(116 \pm 44 ; 8)$ wide. Mature proglottids 1 in number, 336-600 (441 $\pm 79 ; 8)$ long by $110-188(143 \pm 29 ; 8)$ wide. Testes $16-19(17 \pm 1 ; 8)$ in number, 26-55 (38 $\pm 7 ; 7 ; 21)$ long by $21-71(45 \pm 13 ; 7 ; 21)$ wide, extending from anterior margin of proglottid to ovary, slightly overlapping anterior margin of ovary, arranged in 2 regular columns in dorso-ventral view (Fig. 20), 1 row deep; post-ovarian testes absent. Vasa efferentia not observed. Vas deferens extending laterally in proglottid from ootype to cirrus sac. External seminal vesicle not observed. Internal seminal vesicle absent. Cirrus sac pyriform, slightly angled anteriorly, 33-52 (41 \pm 8 ; 7) long by 32-66 (46 \pm 14; 7) wide, containing coiled cirrus. Cirrus microtriches not observed. Ovary H-shaped in dorso-ventral view, bilobed in crosssection, 60-146 (94 \pm 27 ; 7) long by 73-144 (92 \pm 25 ; 7) wide, slightly lobulated, symmetrical; ovarian bridge at middle of ovary. Mehlis' gland near posterior margin of ovary. Vagina extending laterally in proglottid from ootype to genital atrium, opening into genital atrium posterior to cirrus sac. Genital pores lateral, irregularly alternating, 44-49\% $(47 \pm 2 ; 7)$ of proglottid length from posterior end. Uterus saccate, submedial, extending from ovarian bridge to level of anterior-most vitelline follicles. Vitellaria follicular, medullary; follicles arranged in 4 columns, 1 column dorsal and 1 ventral to testes (never lateral to testes) on each lateral margin of proglottid (Figs. 17, 20), extending from anterior margin of ovary to level of second anterior-most row of testes, may overlap ovary, 7-24 (15 $\pm 5 ; 8 ; 24)$ long by 16-46 (28 $\pm 7 ; 8 ; 24)$ wide. Single pair of excretory ducts. Eggs not observed. 


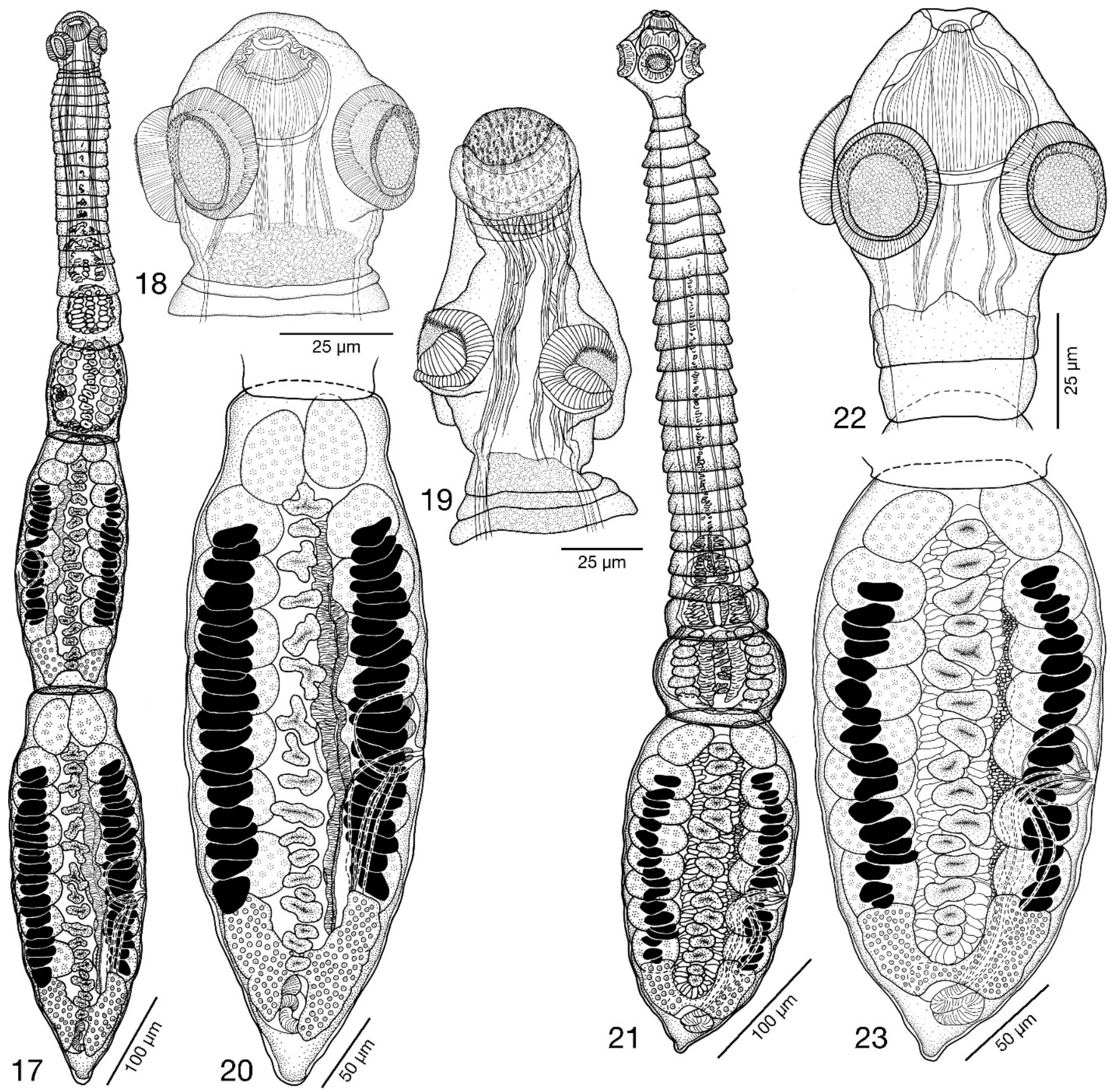

Figures 17-23. Line drawings of Elicilacunosus sarawakensis n. gen., n. sp. (17) Whole worm. (18) Scolex with retracted apical organ. (19) Scolex with protruded apical organ. (20) Mature terminal proglottid. Line drawings of Elicilacunosus dharmadii n. gen., n. sp. (21) Whole worm. (22) Scolex. (23) Mature terminal proglottid.

\section{Taxonomic summary}

Type host: Aetomylaeus maculatus (Gray) (BO-179), the mottled eagle ray (Myliobatiformes: Myliobatidae).

Type locality: Sematan $\left(01^{\circ} 48^{\prime} \mathrm{N}, 109^{\circ} 46^{\prime} \mathrm{E}\right)$, Sarawak, Malaysia, South China Sea.

Site of infection: Spiral intestine.

Specimens deposited: Holotype (MZUM(P) No. 2011.07), 1 paratype (SBC-P-00046); 4 paratypes (USNPC No. 104893); 2 paratypes (LRP Nos. 7712-7713). Two whole worms prepared for SEM retained in the personal collection of K. Jensen at the University of Kansas.

Prevalence: One of 5 host individuals examined (20\%).

Etymology: This species is named for its type locality, the Malaysian State of Sarawak.

\section{Remarks}

Details of the scolex morphology of this species were somewhat difficult to determine because of its small size. In most specimens, 
the scolex was more or less spherical because the anterior region of the apical modification of the scolex proper and the apical organ were withdrawn into the scolex proper. The apical modification of the scolex proper in this condition is domeshaped (Figs. 18, 25), not elongate, with a central aperture. The apical modification was fully extended in only 1 of the 10 specimens examined. In this specimen the apical modification of the scolex proper appeared to be conspicuously elongate (Fig. 19). A more detailed description of the extended apical organ of this species based on additional specimens is required to confirm the observations made here.

\section{Elicilacunosus dharmadii n. sp.}

(Figs. 21-23, 31-40)

Description (based on 17 specimens: 10 whole mounts of mature worms, 6 whole mounts of detached mature proglottids, and 1 whole worm prepared for SEM): Worms 536-906 (689 \pm 110 ; 9) long; maximum width at terminal proglottid, euapolytic; proglottids $15-26(20 \pm 4$; 9) in number. Scolex 43-63 (52 \pm 6 ; 9) long by $47-$ $62(56 \pm 5 ; 9)$ wide, consisting of 4 acetabula, apical modificaton of scolex proper, and apical organ. Acetabula in form of suckers, 24-30 (26 \pm 2 ; 9; 17) long by 21-29 (24 \pm 2 ; 9; 17) wide. Apical modification of scolex proper elongate, cylindrical, partially invaginable, with aperture (Figs. 22, 32) housing apical organ. Apical organ primarily glandular, retractable, 20-29 (25 \pm 4 ; 9) long by $29-34(32 \pm 2 ; 9)$ wide when retracted.

Anterior and lateral acetabular rims with trullate spinitriches and acicular filitriches (Figs. 33, 35); posterior acetabular rims with acicular filitriches only (Fig. 33). Scolex proper with acicular filitriches (Fig. 34). Immature proglottids with papilliform filitriches (Fig. 39). Mature proglottids with capilliform filitriches (Fig. 40), decreasing in length toward posterior margin. Anterior-most region of immature and mature proglottids with small gladiate spinitriches (Fig. 38). Region surrounding tandem series of depressions with small scolopate spinitriches (Fig. 37).

Cephalic peduncle present or absent. Proglottids craspedote, non-laciniate; posterior immature and mature proglottids with region of musculo-glandular tissue along midline of dorsal and ventral surfaces manifested externally as tandem series of depressions (Figs. 31, 36). Immature proglottids 14-25 (19 \pm 4; 9) in number, initially wider than long, becoming slightly longer than wide with maturity; posterior-most immature proglottid 65$129(86 \pm 19 ; 10)$ long by $40-135(94 \pm 24 ; 10)$ wide. Mature proglottids attached to strobila 1 in number, 183-285 (228 \pm 31 ; 10) long by $99-156$ (124 \pm 17 ; 10) wide; detached mature proglottids 311-645 (429 $\pm 125 ; 6)$ long by 171-233 (195 $\pm 24 ; 6)$ wide. Testes $12-17(15 \pm 2 ; 15)$ in number, $11-38(26 \pm 7 ; 10 ; 30)$ long by $12-51(32 \pm 11 ; 10 ; 30)$ wide in attached mature proglottids, 23-50 (35 \pm 9 ; 5; 15) long by $28-69(50 \pm 12 ; 5 ; 15)$ wide in detached mature proglottids, extending from anterior margin of proglottid to ovary, slightly overlapping anterior margin of ovary, arranged in 2 regular columns in dorso-ventral view (Fig. 23), 1 row deep; post-ovarian testes absent. Vasa efferentia not observed. Vas deferens extending laterally in proglottid from ootype to cirrus sac. External seminal vesicle not observed. Internal seminal vesicle absent. Cirrus sac pyriform, slightly angled anteriorly, 28-48 (35 $\pm 5 ; 10)$ long by 26-39 (33 \pm $4 ; 10)$ wide in attached mature proglottids, 53-93 (70 $\pm 15 ; 6)$ long by $45-83(64 \pm 15 ; 6)$ wide in detached mature proglottids, containing coiled cirrus. Cirrus microtriches not observed. Ovary essentially $\mathrm{H}$-shaped in dorso-ventral view, 29-57 (43 $\pm 9 ; 10)$ long by $62-108(85 \pm 15 ; 10)$ wide in attached mature proglottids, 73-156 (106 $\pm 33 ; 5)$ long by 131-171 (150 \pm 16 ; 5) wide in detached mature proglottids, slightly lobulated, symmetrical; ovarian bridge at middle of ovary. Mehlis' gland near posterior margin of ovary. Vagina extending laterally in proglottid from ootype to genital atrium, opening into genital atrium posterior to cirrus sac. Genital pores lateral, irregularly alternating, 44-54\% $(48 \pm 4 ; 10)$ of proglottid length from posterior end in attached mature proglottids, $41-48 \%(44 \pm 3 ; 6)$ of proglottid length from posterior end in detached mature proglottids. Uterus saccate, submedial, extending from ovarian bridge to level of anteriormost vitelline follicles. Vitellaria follicular, medullary; follicles arranged in 4 columns, 1 column dorsal and 1 ventral to testes (never lateral to testes) on each lateral margin of proglottid (Figs. 21, 23), extending from anterior margin of ovary to level of second anterior-most row of testes, slightly overlapping ovary, $7-$ $11(9 \pm 1 ; 5 ; 15)$ long by $17-28(22 \pm 3 ; 5 ; 15)$ wide in attached mature proglottids, $10-32(15 \pm 5 ; 6 ; 18)$ long by $26-68(41 \pm 12$; 6 ; 18) wide in detached mature proglottids. Single pair of excretory ducts. Eggs not observed.

\section{Taxonomic summary}

Type host: Aetomylaeus nichofii (Schneider) sensu stricto (BO34, KA-362), the banded eagle ray (Myliobatiformes: Myliobatidae).

Type locality: Mukah $\left(02^{\circ} 53^{\prime} \mathrm{N}, 112^{\circ} 05^{\prime} \mathrm{E}\right)$, Sarawak, Malaysia, South China Sea.

Additional locality: Sepuk Laut $\left(00^{\circ} 12^{\prime} \mathrm{S}, 109^{\circ} 05^{\prime} \mathrm{E}\right)$, West Kalimantan, Indonesia, South China Sea.

Site of infection: Spiral intestine.

Specimens deposited: Holotype (MZUM(P) No. 2011.06); 2 paratypes (1 whole mount and 1 detached mature proglottid; SBC-P-00044-00045); 8 paratypes (5 whole mounts and 3 detached mature proglottids; USNPC No. 104896); 5 paratypes (3 whole mounts and 2 detached mature proglottids; LRP Nos. 7724-7728). Whole worm prepared for SEM retained in the personal collection of $\mathrm{K}$. Jensen at the University of Kansas. Prevalence: Two of 17 host individuals examined (11.8\%).

Etymology: This species was named for Dharmadi of the Research Centre for Capture Fisheries in Jakarta, Indonesia, for his assistance with host collections.

\section{Remarks}

Elicilacunosus dharmadii n. sp. can be distinguished from $E$. sarawakensis based on its possession of only 1 proglottid close to maturity rather than 2-3 proglottids that are either mature or approaching maturity. This new species is further distinguished from the type species by its shorter ovary (29-57 vs. 60-146), trullate (Fig. 35) rather than coniform (Fig. 27) spinitriches on the acetabular rims, and acicular (Fig. 34) rather than papilliform (Fig. 29) filitriches on the scolex proper. Unfortunately, the apical modification of the scolex proper and the apical organ were not everted in any of the specimens examined; descriptions of both of these structures in this taxon require confirmation. 


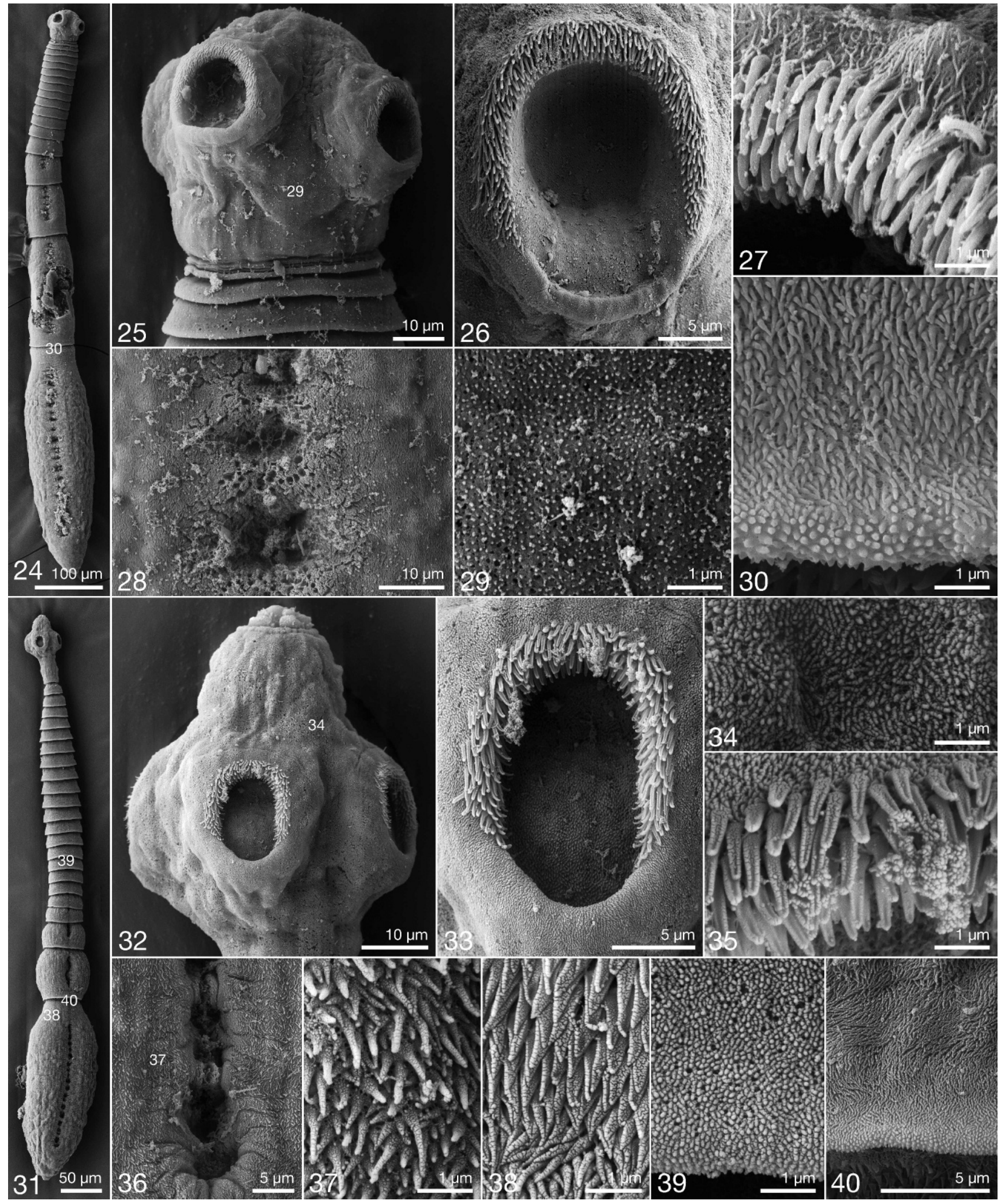

FiguRES 24-30. Scanning electron micrographs of Elicilacunosus sarawakensis n. gen., n. sp. (24) Whole worm. Small number indicates location of detail in Figure 30. (25) Scolex. Small number indicates location of detail in Figure 29. (26) Enlarged view of acetabulum. (27) Acetabular rim with coniform spinitriches and capilliform filitriches; spinitriches absent from posterior margin of rim. (28) Enlarged view of exterior representation of glandular structures. (29) Scolex proper with papilliform filitriches. (30) Proglottid with small scolopate spinitriches, becoming shorter and more conical toward posterior margins of proglottid. 


\section{Elicilacunosus fahmii n. sp.}

(Figs. 41-55)

Description (based on 22 specimens: 1 whole mount of complete mature worm, 2 whole mounts of mature worms without apical organ, 6 whole mounts of mature and 3 whole mounts of immature worms without scolex, 1 whole mount of scolex, 4 whole mounts of detached mature proglottids, 1 whole mount of detached gravid proglottid, 1 semi-permanent lactophenol preparation of eggs, crosssections of 4 mature proglottids [2 detached mature proglottids $P A S$ stained], and 1 scolex prepared for SEM): Worms 2,117$2,662(2,450 \pm 292 ; 3)$ long; maximum width at terminal proglottid, euapolytic; proglottids $34-51(42 \pm 6$; 7) in number. Scolex $298(\mathrm{n}=1)$ long by 65-125 (105 \pm 27 ; 4) wide, consisting of 4 acetabula, apical modificaton of scolex proper, and apical organ. Acetabula in form of suckers, 37-60 (53 $\pm 8 ; 4 ; 8)$ long by 34-61 $(50 \pm 9 ; 4 ; 8)$ wide. Apical modification of scolex proper long, cylindrical (Figs. 41, 46), invaginable into scolex proper, with aperture, housing apical organ. Apical organ primarily glandular, retractable, $105(n=1)$ long by $45(n=1)$ wide.

Acetabular rims with trullate spinitriches and acicular and papilliform filitriches (Figs. 47, 48). Distal acetabular surface with acicular and papilliform filitriches. Scolex proper and posterior region of apical modification of scolex proper with capilliform filitriches, giving scolex "fuzzy" appearance (Figs. 46, 49). Anterior region of apical modification of scolex proper with papilliform filitriches (Fig. 51). Proglottids with acicular and papilliform filitriches (Fig. 52).

Cephalic peduncle present. Proglottids craspedote, nonlaciniate; posterior immature and mature proglottids with region of musculo-glandular tissue along midline of dorsal and ventral surfaces manifested externally as tandem series of depressions (Figs. 43, 53-55). Immature proglottids 34-51 (41 \pm 6 ; 7) in number, initially wider than long, becoming longer than wide with maturity; posterior-most immature proglottid 218-378 (277 $\pm 52 ; 11)$ long by $180-319(235 \pm 48 ; 11)$ wide. Mature proglottids attached to strobila 1 in number, 321-603 (403 \pm 90; 8) long by 190-307 (249 \pm 49; 8) wide; detached mature proglottids $428-575(499 \pm 81$; 4) long by 228-322 (264 \pm 41 ; 4) wide. Detached gravid proglottids, 1,024 ( $\mathrm{n}=1)$ long by $467(\mathrm{n}=1)$ wide. Testes $24-33(28 \pm 3 ; 14)$ in number, 9-46 $(26 \pm 9 ; 10 ; 30)$ long by $23-102(64 \pm 21 ; 10 ; 30)$ wide in attached mature proglottids, $23-52(35 \pm 10 ; 4 ; 12)$ long by $36-$ $119(78 \pm 23 ; 4 ; 12)$ wide in detached mature proglottids, extending from anterior margin of proglottid to ovary, overlapping ovary, arranged in 2 regular columns in dorso-ventral view (Fig. 43), 1 row deep in cross-section (Figs. 53, 55). Vasa efferentia not observed. Vas deferens in form of thick tube, extending laterally in proglottid from ootype to cirrus sac. External seminal vesicle not observed. Internal seminal vesicle absent. Cirrus sac pyriform, 31-122 (75 \pm 33 ; 10) long by 29-58 $(41 \pm 11 ; 190)$ wide in attached mature proglottids, 45-152 (95 \pm 43 ; 5) long by 41-144 (75 $\pm 42 ; 5)$ wide in detached mature proglottids, containing coiled cirrus. Cirrus microtriches not observed. Ovary H-shaped in dorso-ventral view, bilobed in cross-section (Fig. 54); 26-129 (75 \pm 33; 9) long by 139-217 (176 \pm 35 ; 9) wide in attached mature proglottids, 59-229 (111 \pm 70 ; 5) long by $152-354(221 \pm 79$; 5) wide in detached mature proglottids, slightly lobulated, symmetrical; ovarian bridge at middle of ovary. Mehlis' gland near posterior margin of ovary. Vagina extending laterally in proglottid from ootype to genital atrium, opening into genital atrium posterior to cirrus sac. Genital pores lateral, irregularly alternating, 32-55\% (50 \pm 7 ; 10) of proglottid length from posterior end in attached mature proglottids, 38-52\% (45 \pm 5 ; 5) of proglottid length from posterior end in detached mature proglottids. Uterus saccate, submedial, extending from ovarian bridge to level of anteriormost vitelline follicles. Vitellaria follicular, medullary (Fig. 53); follicles arranged in 4 columns, 1 column dorsal and 1 ventral to testes (never lateral to testes) on each lateral margin of proglottid (Figs. 42, 43), extending from anterior margin of ovary to near anterior margin of proglottid, slightly overlapping ovary, $8-21(13 \pm 4 ; 5 ; 15)$ long by $25-51(39 \pm 10 ; 5 ; 15)$ wide in attached mature proglottids, $10-53(20 \pm 11 ; 5 ; 15)$ long by $31-150(61 \pm 35 ; 5 ; 15)$ wide in detached mature proglottids. Single pair of excretory ducts (Fig. 54). Eggs oval, 13-16 (15 \pm 1 ; 5) long by 19-23 (21 \pm 2 ; 5) wide, with bipolar filaments (Fig. 45); polar filaments equal in length, 62-100 (83 $\pm 12 ; 5$; 10) long.

\section{Taxonomic summary}

Type host: Aetomylaeus nichofii (Schneider) sensu stricto (KA362), the banded eagle ray (Myliobatiformes: Myliobatidae).

Type locality: Sepuk Laut $\left(00^{\circ} 12^{\prime} \mathrm{S}, 109^{\circ} 05^{\prime} \mathrm{E}\right)$, West Kalimantan, Indonesia, South China Sea.

Site of infection: Spiral intestine.

Specimens deposited: Holotype (whole mount of mature worm without apical organ; MZBCa No. 162), 2 paratypes (1 whole mount of mature worm without scolex and 1 detached mature proglottid; MZBCa Nos. 163-164); 12 paratypes (1 whole mount of complete mature worm, 1 whole mount of mature worm without apical organ, 2 whole mounts of mature worms without scoleces, 2 whole mounts of immature worms without scoleces, 2 detached mature proglottids, 1 detached gravid proglottid, 1 semipermanent lactophenol preparation of eggs, and cross-sections of 2 mature proglottids [1 PAS stained]; USNPC No. 104894); 7 paratypes (1 whole mount of scolex, 2 whole mounts of mature worms without scoleces [including strobilar voucher of scolex prepared for SEM], 1 whole mount of immature worm without scolex, 1 detached mature proglottid, and cross-sections of 2 mature proglottids [1 PAS stained]; LRP Nos. 7714-7723). Scolex prepared for SEM retained in the personal collection of K. Jensen at the University of Kansas.

$\leftarrow$

FIgures 31-40. Scanning electron micrographs of Elicilacunosus dharmadii n. gen., n. sp. (31) Whole worm. Small numbers indicate location of detail in Figures 38-40. (32) Scolex. Small number indicates location of details in Figure 34. (33) Enlarged view of acetabulum. (34) Scolex proper with acicular filitriches. (35) Acetabular rim with trullate spinitriches and acicular filitriches; spinitriches absent from posterior margin of rim. (36) Enlarged view of external representation of glandular structures. Small number indicates location of detail in Figure 37. (37) Region surrounding external representation of glandular structures with small scolopate spinitriches. (38) Anterior region of terminal proglottid with small gladiate spinitriches. (39) Posterior margin of anterior proglottid with papilliform filitriches, decreasing in length toward posterior margin. (40) Posterior margin of subterminal proglottid with capilliform filitriches, decreasing in length toward posterior margin. 




FIgURES 41-45. Line drawings of Elicilacunosus fahmii n. gen., n. sp. (41) Scolex. (42) Whole worm. (43) Mature terminal proglottid. Arrows indicate level of cross-sections in Figures 53-55. (44) Detail of terminal genitalia. (45) Eggs.

Prevalence: One of 17 host individuals examined (5.9\%).

Etymology: This species was named for Fahmi of the Pusat Penelitian Oseanografi, Indonesian Institute of Sciences (LIPI), in Jakarta, Indonesia, for his assistance with host collections.

\section{Remarks}

Elicilacunosus fahmii n. sp. can be easily distinguished from $E$. sarawakensis and $E$. dharmadii based on its greater total length 

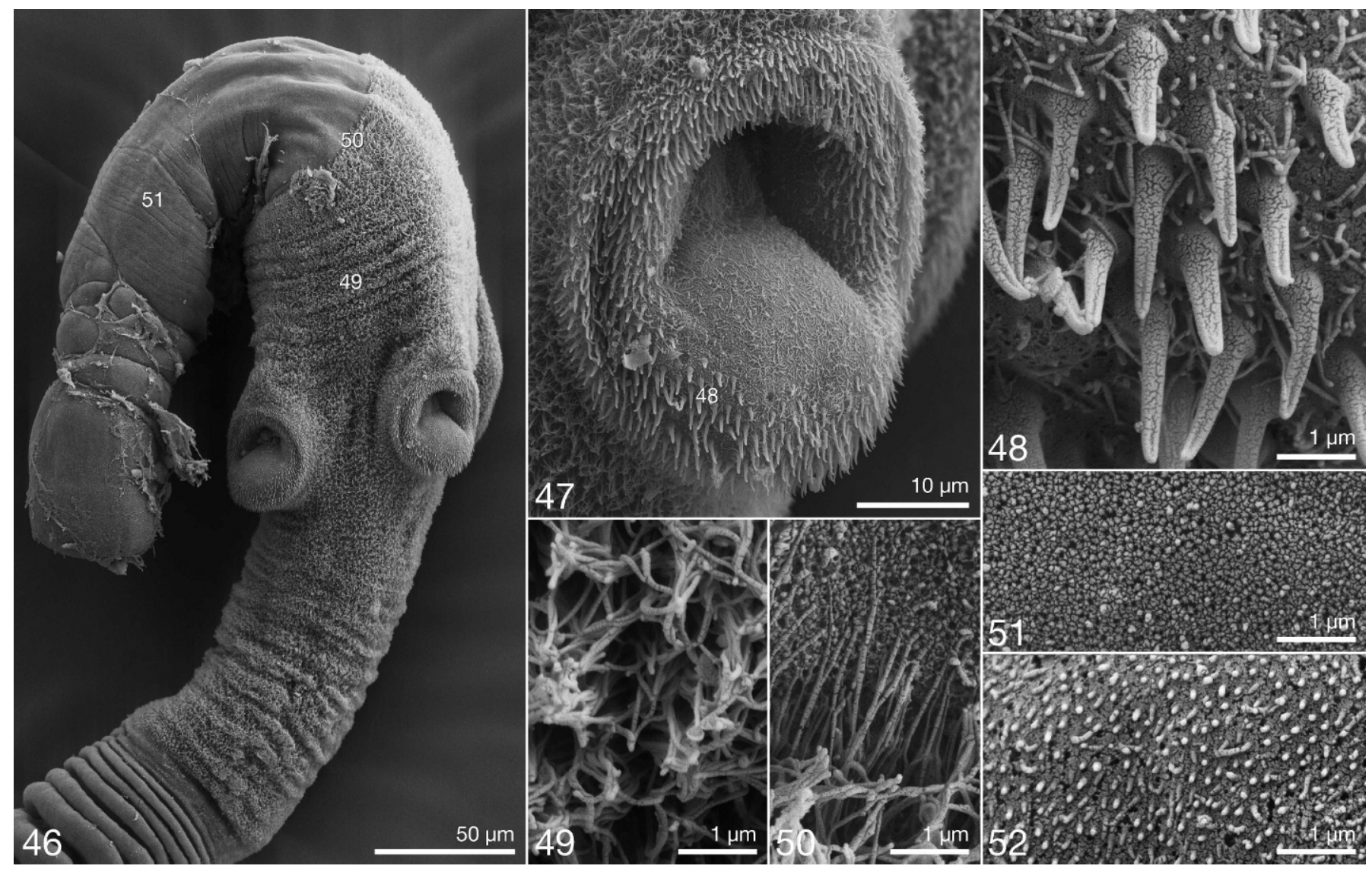

Figures 46-52. Scanning electron micrographs of Elicilacunosus fahmii n. gen., n. sp. (46) Scolex. Small numbers indicate detail in Figures 49-51. (47) Enlarged view of acetabulum. Small number indicates detail in Figure 48. (48) Acetabular rim with trullate spinitriches and acicular and papilliform filitriches. (49) Scolex proper with capilliform filitriches. (50) Interface between scolex proper and apical organ. (51) Apical organ with papilliform filitriches. (52) Proglottids with acicular and papilliform filitriches.

(2,117-2,662 vs. 536-906, and 890-1,830, respectively), as well as its greater number of proglottids (34-51 vs. 15-26, and 18-24, respectively). In addition, whereas the spinitriches cover only the anterior margin of the acetabular rim of E. sarawakensis and $E$. dharmadii, they are present throughout the entire acetabular rim in E. fahmii. Moreover, the apical organ is much more extensive in this species than it is in either of its congeners. Also, rather than covered with acicular filitriches, the entire scolex proper of $E$. fahmii is covered with capilliform filitriches, giving it a "fuzzy" appearance (Fig. 46).

The selective staining of proglottid cross-sections of E. fahmii for glycoproteins or mucopolysaccharides using the McManus' PAS protocol showed PAS-positive staining of the region surrounding what appears to be musculo-glandular tissue, especially toward the center of the proglottid (Fig. 55). This result supports, but does not allow us to conclusively assign, an adhesive function to these tissues.

\section{Rexapex n. gen.}

Diagnosis: Worms euapolytic. Scolex bearing 4 acetabula, apical modification of scolex proper, and apical organ. Acetabula bothridiate in form. Apical modification of scolex proper with aperture at center housing apical organ. Apical organ muscular, non-glandular, retractable, in form of inverted cone, with 18 papilliform projections around its perimeter. Cephalic peduncle absent. Proglottids craspedote, non-laciniate. Anterior-most immature proglottids conspicuously laterally expanded. Testes arranged in single column, anterior to ovarian bridge. Vas deferens expanded to form external seminal vesicle. External seminal vesicle saccate, extending from ootype to anterior margin of cirrus sac. Internal seminal vesicle absent. Cirrus sac pyriform. Cirrus unarmed. Ovary H-shaped in dorso-ventral view, bilobed in cross-section. Vagina extending laterally in proglottid from ootype to genital atrium, opening into genital atrium posterior to cirrus sac. Genital pores lateral, irregularly alternating. Uterus medial, saccate. Vitellaria follicular, medullary; follicles arranged in 1 dorsal and 1 ventral column on each lateral margin of proglottid, extending from anterior margin of ovary to near anterior margin of proglottid. Single pair of excretory ducts. Eggs unknown. In spiral intestine of Aetomylaeus (Myliobatidae), Northern Australia.

\section{Taxonomic summary}

Type and only species: Rexapex nanus n. gen., n. sp.

Etymology: Rex, L. king. This genus was named for its apical organ, which, when everted, resembles a crown. 

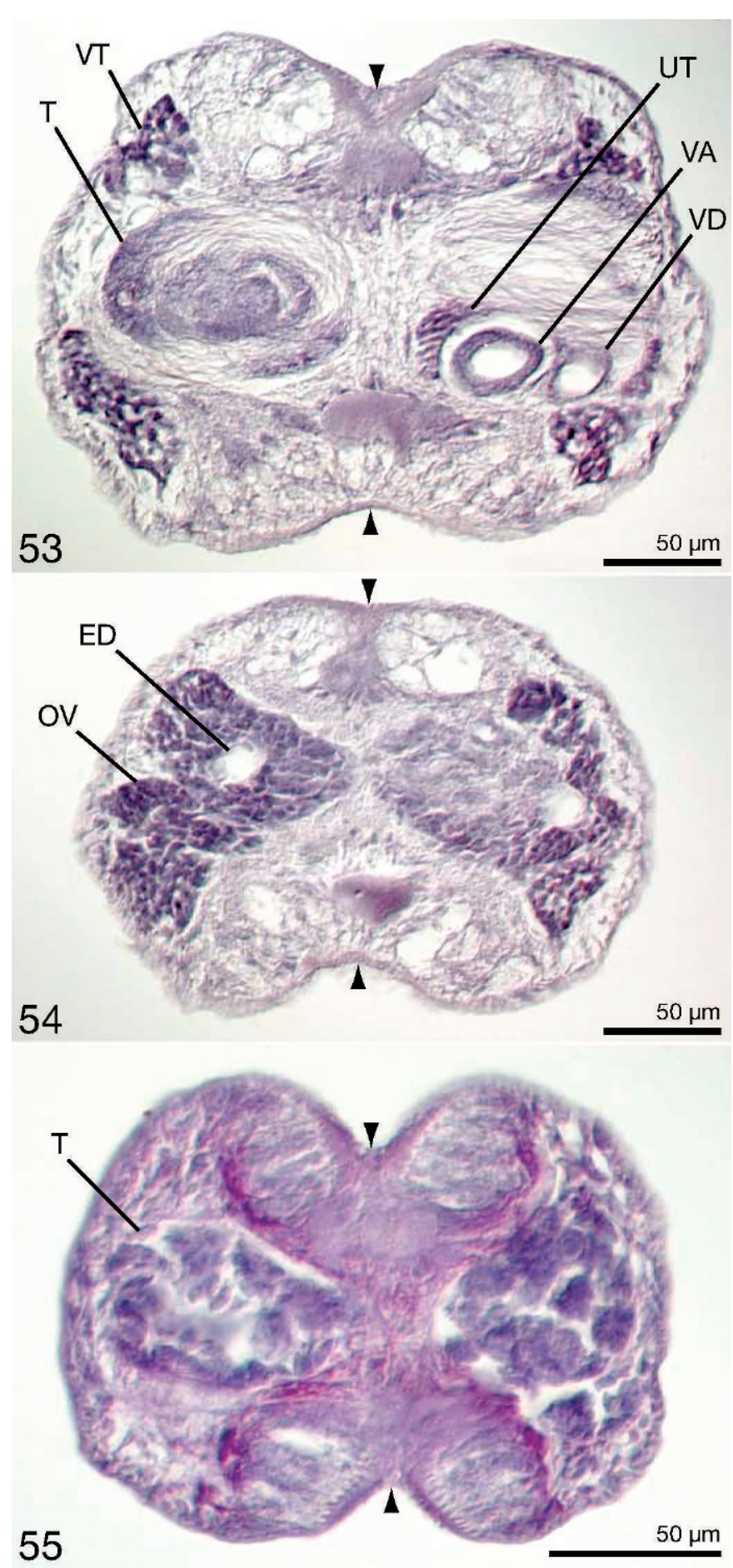

Figures 53-55. Elicilacunosus fahmii n. gen., n. sp. (53) Cross-section through mature proglottid between genital pore and ovary. (54) Crosssection through mature proglottid at level of ovary. (55) Cross-section through mature proglottid anterior to genital pore (PAS stained); musculo-glandular tissue stains PAS positive around its periphery. Abbreviations: ED, excretory duct; OV, ovary; T, testis; UT, uterus; VA, vagina; VD, vas deferens; VT, vitelline follicle. Arrows indicate center of dorsal and ventral regions of musculo-glandular tissue.

\section{Remarks}

In combination, its possession of a scolex with 4 acetabula, an apical organ, a vagina opening into the genital atrium posterior to the cirrus sac, and an extensive external seminal vesicle, firmly places this new genus within the Lecanicephalidea. Rexapex $\mathrm{n}$. gen. conspicuously differs from Paraberrapex and Aberrapex in its possession of an apical organ. It differs from the remaining 14 lecanicephalidean genera in the unusual shape of its apical organ, which resembles a crown, i.e., consisting of an apical muscular pad bearing 18 papilliform projections around its perimeter. It can further be distinguished from Collicocephalus, Eniochobothrium, Healyum, Hexacanalis, Lecanicephalum, Tetragonocephalum, and Tylocephalum in its possession of testes arranged in a single column, rather than in 2 or more columns. Despite the superficial resemblance of the papilliform projections of its apical organ to the tentacles of Polypocephalus, the 2 genera differ in that the projections of the apical organ of Rexapex $\mathrm{n}$. gen. are withdrawn, rather than invaginated, when the apical organ is retracted into the apical modification of the scolex proper. In addition, whereas the anterior immature proglottids of Rexapex n. gen. are laterally expanded, those of Polypocephalus are not; furthermore, whereas Rexapex $\mathrm{n}$. gen. bears a single pair of excretory ducts, Polypocephalus bears 2 pairs of excretory ducts. It differs from Elicilacunosus in lacking the region of musculo-glandular tissue along the midline of the dorsal and ventral surfaces of the proglottids. Whereas the ovary of Rexapex $\mathrm{n}$. gen. is bilobed in cross-section, the ovaries of Corrugatocephalum and Quadcuspibothrium are trilobed in crosssection. Anteropora and Sesquipedalapex are hyperapolytic, while Rexapex $\mathrm{n}$. gen. is euapolytic. Superficially, Rexapex $\mathrm{n}$. gen. is most similar to Hornellobothrium, particularly in the laterally expanded nature of its anterior immature proglottids. However, its possession of an eversible, highly muscular apical organ (rather than a noneversible glandular apical organ) readily distinguishes Rexapex $\mathrm{n}$. gen. from Hornellobothrium.

\section{Rexapex nanus $\mathrm{n} . \mathbf{s p}$.}

(Figs. 56-71)

Description (based on 19 specimens: 14 whole mounts of mature worms, 1 whole mount of immature worm, cross-sections of 2 mature proglottids, and 2 whole worms prepared for SEM): Worms 910-2,017 (1,414 $\pm 363 ; 14)$ long; maximum width at terminal proglottid, euapolytic; proglottids $22-30(25 \pm 2 ; 14)$ in number. Scolex 43-58 (51 $\pm 5 ; 14)$ long by 39-70 $(55 \pm 10 ; 14)$ wide with apical organ retracted, $70(n=1)$ long by $52(n=1)$ wide with apical organ everted, consisting of 4 acetabula, apical modificaton of scolex proper, and apical organ. Acetabula bothridiate in form, cup-shaped, free anteriorly and posteriorly, 23-31 (27 \pm 2 ; 12 ; 22) long by $20-29(25 \pm 2 ; 12 ; 22)$ wide. Apical modification of scolex proper with aperture at center housing apical organ. Apical organ muscular, non-glandular, retractable (Fig. 58), in form of inverted cone, with 18 short, papilliform projections around its perimeter (Figs. 57, 61), 36-50 (44 \pm 4 ; 14) long by $32-59(47 \pm 9 ; 14)$ wide when retracted, $74(\mathrm{n}=1)$ long by 59 $(\mathrm{n}=1)$ wide when everted.

Anterior and lateral acetabular rims with trullate spinitriches and capilliform filitriches (Figs. 63, 64); posterior acetabular rims with capilliform filitriches only (Fig. 63). Distal acetabular surface and scolex proper with acicular filitriches (Fig. 66); anterior margin of apical modification of scolex proper with 
small gladiate spinitriches forming band around base of everted apical organ (Figs. 61, 65). Proglottids with capilliform filitriches and small scolopate spinitriches along posterior proglottid margin (Figs. 67, 68).

Cephalic peduncle absent. Proglottids craspedote, non-laciniate. Anterior immature proglottids conspicuously laterally expanded. Immature proglottids $21-29$ (24 \pm 2 ; 14) in number, initially wider than long, becoming longer than wide with maturity; posterior-most immature proglottid 149-485 (264 \pm 91; 14) long by $85-162(111 \pm 26 ; 14)$ wide. Mature proglottids $1-2$ in number, 394-844 (589 $\pm 130 ; 14)$ long by 100-193 (146 \pm 25 ; 14) wide. Testes $9-14(12 \pm 1 ; 14)$ in number, $17-66$ (31 \pm 13 ; $14 ; 42)$ long by $32-92(63 \pm 16 ; 14 ; 42)$ wide, extending from anterior margin of proglottid to ovarian bridge, 1 column in dorso-ventral view (Figs. 56, 59), 1 row deep in cross-section (Figs. 69, 70), may be degenerated in terminal mature proglottid; post-ovarian testes absent. Vas efferens not observed. Vas deferens extending laterally in proglottid from ootype to anterior margin of cirrus sac, enlarged to form external seminal vesicle in mature proglottids in which testes are degenerated. External seminal vesicle extensive, saccate, extending more or less laterally in proglottid from ootype to anterior margin of cirrus sac. Internal seminal vesicle absent. Cirrus sac pyriform, slightly angled anteriorly, 58-106 (80 $\pm 14 ; 14)$ long by 43-88 (69 \pm 14 ; 14) wide, containing coiled cirrus. Cirrus microtriches absent. Ovary $\mathrm{H}$-shaped in dorso-ventral view, bilobed in cross-section (Fig. 71), 56-301 (169 \pm 59 ; 14) long by 68-155 (100 $\pm 24 ; 14)$ wide, slightly lobulated, symmetrical; ovarian bridge at middle of ovary. Mehlis' gland present posterior to ovarian bridge. Vagina extending laterally in mature proglottids with testes (more medially in mature proglottids in which testes are degenerated) from ootype to genital atrium, opening into genital atrium posterior to cirrus sac. Genital pores lateral, irregularly alternating, 48-63\% (56 \pm 4 ; 14) of proglottid length from posterior end. Uterus saccate, extending medially in proglottid from ovarian bridge to level of anterior margin of vitelline follicles. Vitellaria follicular, medullary; vitelline follicles arranged in 4 columns, 1 dorsal and 1 ventral column on each lateral margin of proglottid in cross-section (Fig. 69), extending from anterior margin of ovary to near anterior margin of proglottid, may slightly overlap ovary, 10-41 (21 \pm 8 ; 14; 42) long by $13-75(35 \pm 16 ; 14 ; 42)$ wide. Single pair of excretory ducts (Fig. 70). Eggs not observed.

\section{Taxonomic summary}

Type and only known host: Aetomylaeus vespertilio (Bleeker) (CM03-61), the ornate eagle ray (Myliobatiformes: Myliobatidae).

Type and only known locality: Off Weipa $\left(12^{\circ} 40^{\prime} \mathrm{S}, 141^{\circ} 52^{\prime} \mathrm{E}\right)$ in the Gulf of Carpentaria, Queensland, Australia.

Site of infection: Spiral intestine.

Specimens deposited: Holotype (QM No. G233489), 5 paratypes (4 whole mounts and 1 proglottid cross-section; QM Nos. G233490-233494); 6 paratypes (USNPC No. 104890); 5 paratypes (4 whole mounts and 1 proglottid cross-section; LRP Nos. 7694-7700). Two whole worms prepared for SEM retained in the personal collection of K. Jensen at the University of Kansas.

Prevalence: One of 5 host individuals examined (20\%).

Etymology: nanus, L. dwarf. This species was named for its small size.

\section{Aberrapex weipaensis n. sp.}

(Figs. 72-80)

Description (based on 14 specimens: 12 whole mounts of mature worms, cross-sections of 1 mature proglottid, and 1 whole worm prepared for SEM): Worms 475-1,902 (1,174 \pm 410 ; 12) long, maximum width at terminal proglottid, euapolytic; proglottids $21-28(24 \pm 3 ; 12)$ in number. Scolex 40-63 (52 \pm 7 ; 11) long by 62-79 (70 $\pm 5 ; 6)$ wide, consisting of 4 acetabula. Acetabula bothridiate in form, cup-shaped, 46-56 (51 \pm 3 ; 9) long by 33-43 $(37 \pm 3 ; 9)$ wide. Apical modification of scolex proper and apical organ absent (Figs. 73, 76).

Proximal acetabular surface with hastate spinitriches and acicular filitriches (Fig. 79). Distal acetabular surface with acicular filitriches (Fig. 77), apex of scolex proper with papilliform filitriches (Fig. 78). Proglottids with capilliform filitriches, becoming shorter toward posterior proglottid margin (Fig. 80).

Cephalic peduncle absent. Proglottids craspedote, non-laciniate. Immature proglottids $20-27(23 \pm 3 ; 12)$ in number, initially wider than long, becoming longer than wide with maturity; posterior-most immature proglottid 76-393 (156 $\pm 85 ; 11)$ long by $83-129(103 \pm 14 ; 11)$ wide. Mature proglottids $1-2$ in number; terminal mature proglottids with testes $288-462(405 \pm 71 ; 5)$ long by $117-159(137 \pm 15 ; 5)$ wide; terminal mature proglottids in which most testes are degenerated 409-774 (562 $\pm 120 ; 7)$ long by $135-173(150 \pm 13 ; 7)$ wide. Testes $10-17(14 \pm 3 ; 10)$ in number, $12-33(24 \pm 6 ; 8)$ long by $31-69(49 \pm 11 ; 8)$ wide, extending from ovary to near anterior margin of proglottid, slightly overlapping anterior margin of ovary, 1-2 irregular columns in dorso-ventral view (Fig. 72), 1 row deep in cross-section, degenerated in terminal mature proglottid; post-ovarian testes absent. Vasa efferentia not observed. Vas deferens extending laterally in proglottid from ootype to anterior margin of cirrus sac, enlarged to form external seminal vesicle in terminal mature proglottids in which testes are degenerated. External seminal vesicle extensive, saccate, extending more or less medially in proglottid from ootype to approximately half-way between anterior margin of cirrus sac and anterior margin of vitellaria. Internal seminal vesicle absent. Cirrus sac pyriform, slightly angled anteriorly, 29-42 (38 \pm 6 ; 4) long by 55-65 $(59 \pm 4 ; 4)$ wide in maturing proglottids with testes, $62-105(84 \pm 15 ; 7)$ long by $25-73(52 \pm 17 ; 7)$ wide in terminal mature proglottids in which testes are degenerated, containing coiled cirrus. Cirrus microtriches absent. Ovary H-shaped in dorso-ventral view, tetralobed in cross-section, 93-106 (98 \pm 6 ; 4) long by $72-114(95 \pm 17 ; 4)$ wide in maturing proglottids with testes, 118-272 (202 \pm 46 ; 7) long by 89-122 (100 \pm 11 ; 7) wide in terminal mature proglottids in which testes are degenerated, slightly lobulated, symmetrical; ovarian bridge at middle of ovary. Mehlis' gland near posterior margin of ovary. Vagina extending laterally in mature proglottids with testes (more medially in terminal mature proglottids in which testes are degenerated) from ootype to genital atrium, opening into genital atrium posterior to cirrus sac. Genital pores lateral, irregularly alternating, 58-65\% $(62 \pm 3 ; 4)$ of proglottid length from posterior end in mature proglottids with testes, $58-63 \%(61 \pm 2 ; 7)$ in terminal mature proglottids in which testes are degenerated. Uterus saccate, extending medially in proglottid from ovarian bridge to level of anterior margin of vitellaria. Vitellaria follicular, medullary; arranged in 4 columns, 1 dorsal and 1 ventral column on lateral margin of proglottid, extending from anterior margin of ovary to 

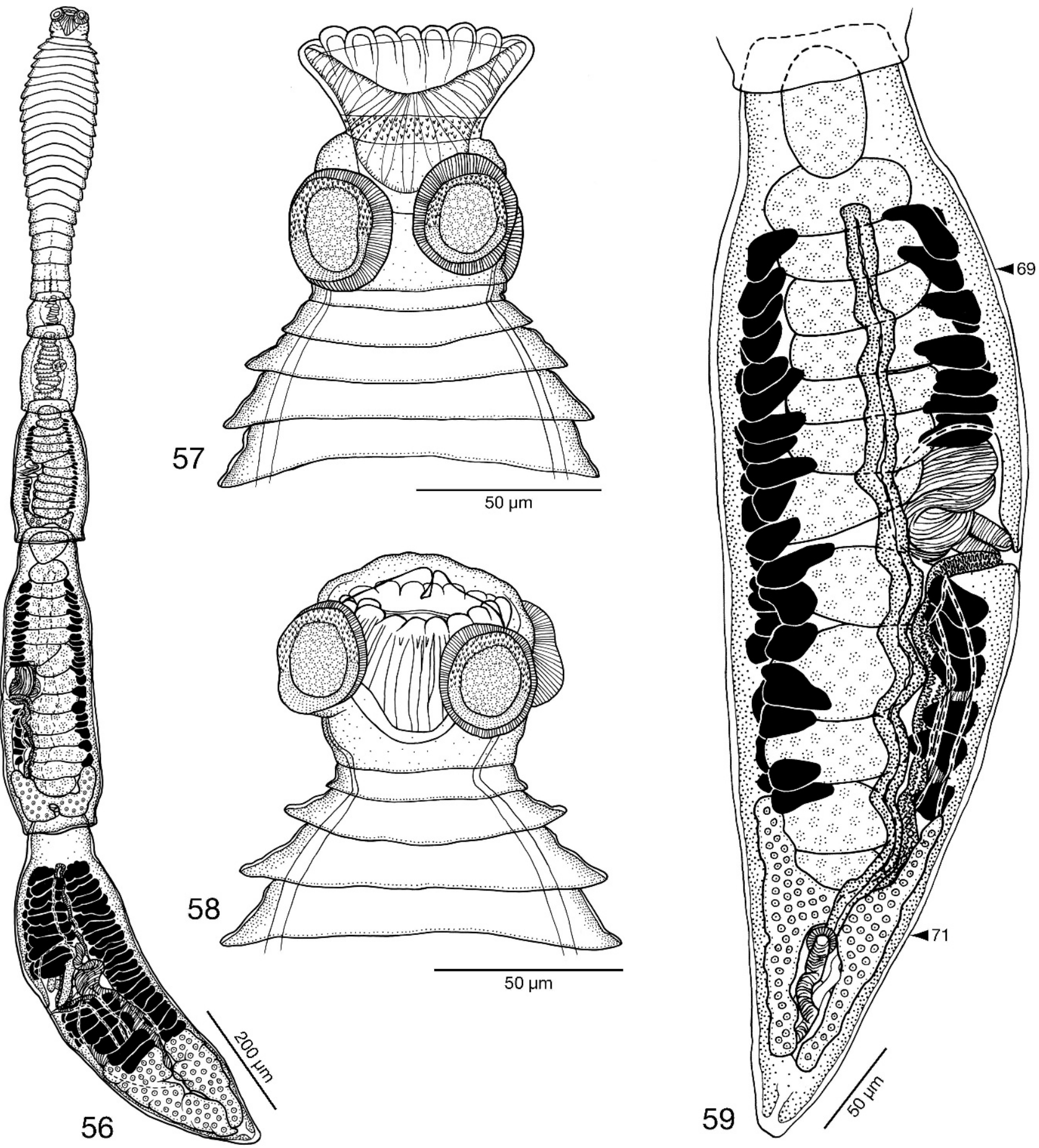

FiguRES 56-59. Line drawings of Rexapex nanus n. gen., n. sp. (56) Whole worm. (57) Scolex with apical organ everted. (58) Scolex with apical organ retracted. (59) Mature terminal proglottid. Arrows indicate level of cross-sections in Figures 69 and 71.

near anterior margin of proglottid, slightly overlapping ovary, 9 $21(13 \pm 4 ; 3 ; 9)$ long by $9-29(21 \pm 6 ; 3 ; 9)$ wide in mature proglottids with testes, $11-29(19 \pm 5 ; 7 ; 21)$ long by $26-52(39 \pm$ $8 ; 7 ; 21)$ wide in terminal mature proglottids in which testes are degenerated; post-ovarian vitelline follicles absent. Single pair of excretory ducts. Eggs not observed.

\section{Taxonomic summary}

Type host: Aetomylaeus vespertilio (Bleeker) (CM03-61), the ornate eagle ray (Myliobatiformes: Myliobatidae).

Additional hosts: None.

Site of infection: Spiral intestine. 


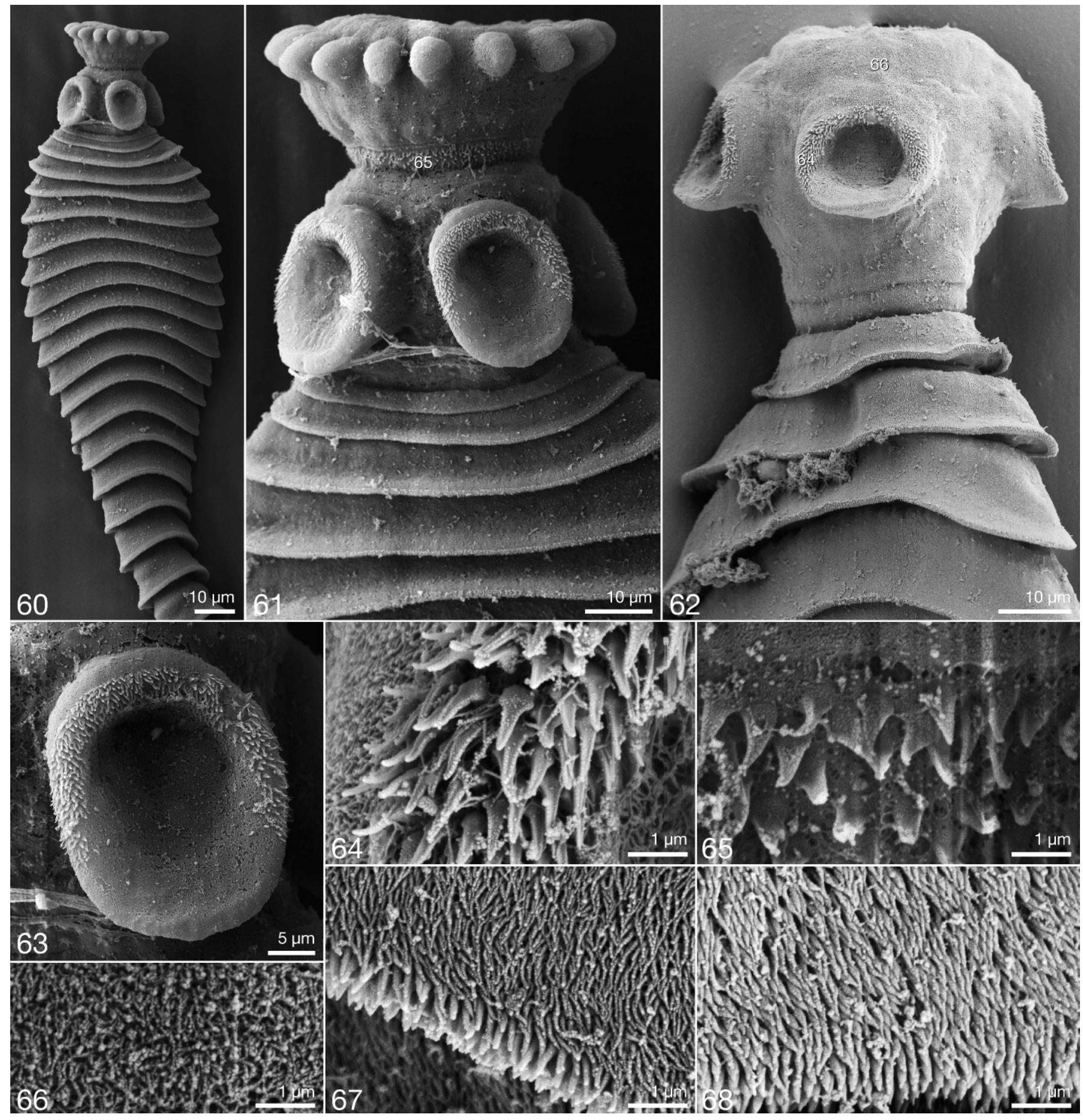

FiguRES 60-68. Scanning electron micrographs of Rexapex nanus n. gen., n. sp. (60) Scolex and anterior strobila. (61) Scolex with apical organ everted. Small number indicates location of detail in Figure 65. (62) Scolex with apical organ retracted. Small numbers indicate location of detail in Figures 64 and 66. (63) Enlarged view of acetabulum. (64) Acetabular rim with trullate spinitriches and capilliform filitriches. (65) Anterior margin of apical modification of scolex proper with gladiate spinitriches forming band around base of everted apical organ. (66) Scolex proper with acicular filitriches. (67) Anterior proglottids with capilliform filitriches and small scolopate spinitriches along posterior margin. (68) Posterior proglottids with capilliform filitriches and small scolopate spinitriches along posterior margin.

Type locality: Off Weipa $\left(12^{\circ} 40^{\prime} \mathrm{S}, 141^{\circ} 52^{\prime} \mathrm{E}\right)$, Queensland, Gulf of Carpentaria, Australia.

Specimens deposited: Holotype (QM No. G233495), 3 paratypes (QM Nos. G233496-233498); 5 paratypes (USNPC
No. 104891); 4 paratypes (3 whole mounts and cross-section of 1 proglottid; LRP Nos. 7689-7693). Whole worm prepared for SEM retained in the personal collection of $\mathrm{K}$. Jensen at the University of Kansas. 


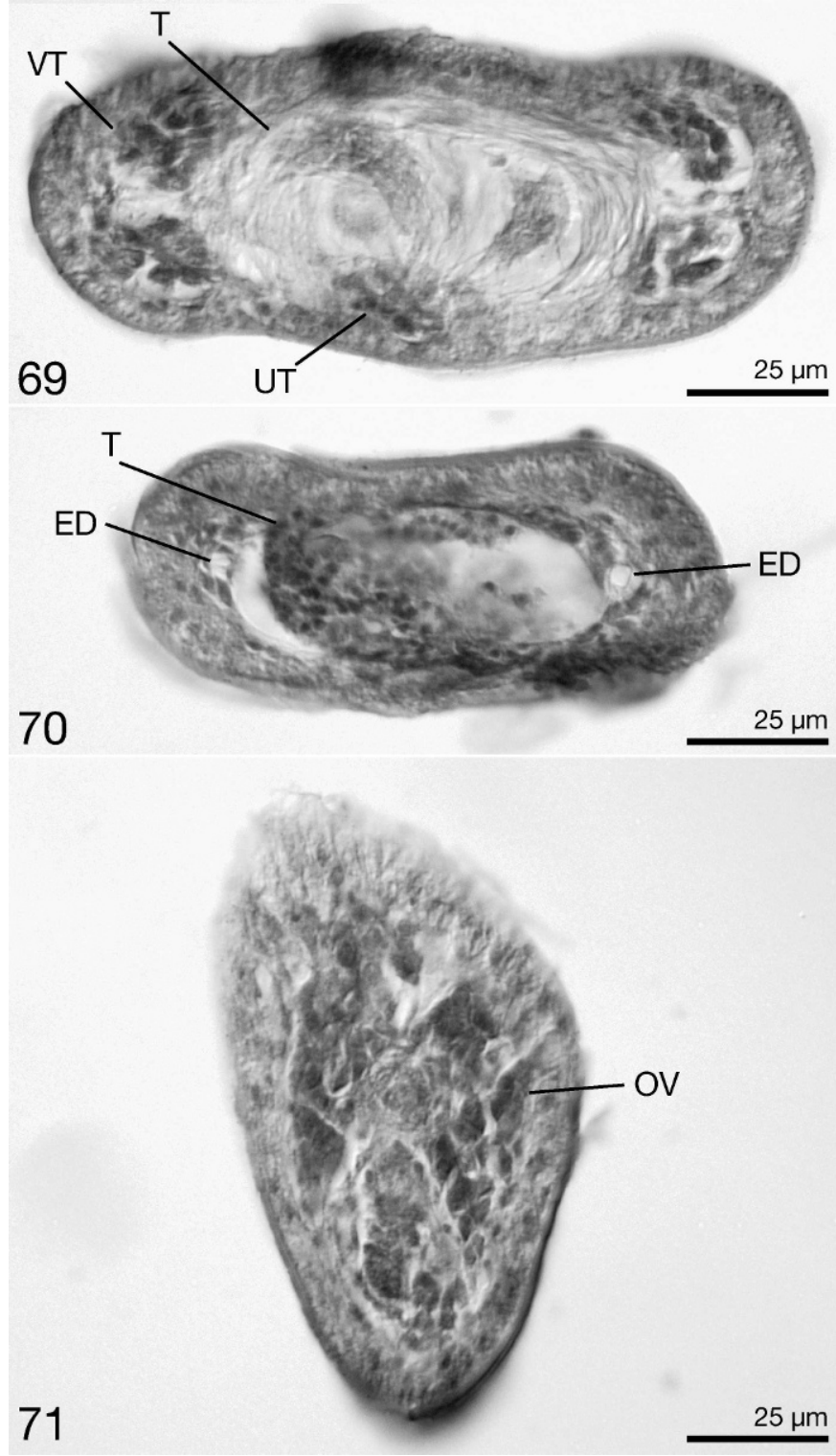

FIgURES 69-71. Rexapex nanus n. gen., n. sp. (69) Cross-section through mature proglottid anterior to genital pore. (70) Cross-section through maturing proglottid anterior to genital pore, showing 2 excretory ducts. (71) Cross-section through mature proglottid at level of ovary. Abbreviations: ED, excretory duct; ESV, external seminal vesicle; OV, ovary; T, testis; VT, vitelline follicle.

Prevalence: Two of 5 host individuals examined (40\%).

Etymology: This species is named for its type locality, off Weipa, Queensland, Australia.

\section{Remarks}

This species is consistent with the generic diagnosis of Aberrapex in its lack of both an apical modification of the scolex proper and an apical organ and in its possession of an unarmed cirrus and of an external seminal vesicle that originates at the level of the ovary. Moreover, like the other species of Aberrapex, the vagina extends along the lateral margin of the proglottid in mature proglottids with testes, while in mature proglottids in which testes are degenerated, the vagina extends more medially in the proglottid.

Currently, 3 species are recognized as valid in Aberrapex, i.e., Aberrapex senticosus Jensen, 2001; Aberrapex arrhynchum (Brooks, Mayes, and Thorson 1981) Jensen, 2005; and Aberrapex manjajiae Jensen, 2006. Aberrapex weipaensis n. sp. differs from all 3 species in its smaller scolex (40-63 long by $62-79$ wide vs. $100-130$ long by $125-170$ wide, $177-186$ long by $233-326$ wide, and 82-101 long by 119-164 wide, respectively) and its lack of vitelline follicles posterior to the ovary; the other 3 species have vitellaria that extend posterior to the ovary. Aberrapex weipaensis n. sp. can further be distinguished from A. senticosus in its possession of a smaller number of testes (10-17 vs. $20-40)$, a smaller cirrus sac in those proglottids in which testes have degenerated (37105 long by $25-88$ wide vs. $127-182$ long by $130-150$ wide), and a shorter ovary in proglottids in which testes have degenerated (118272 vs. 335-444). Aberrapex weipaensis n. sp. further differs from A. arrhynchum in having fewer proglottids (21-28 vs. $43-48)$ and from A. manjajiae in having a genital pore located much more posteriorly (58-65\% vs. $76-85 \%)$.

\section{Additional members of the lecanicephalidean fauna of the target Aetomylaeus species}

In the interest of promoting future work on the lecanicephalidean faunas of the 4 species of Aetomylaeus examined here, we note that the 3 new genera and 6 new species of lecanicephalideans treated above represent only a subset of the potentially new taxa encountered in these 4 host species over the course of this study. Although we concentrated on the cestode taxa for which sufficient high quality material was available for study, small numbers of specimens of the following taxa were also seen. Aetomylaeus vespertilio hosted as many as 6 new species of Tylocephalum, 2 new species of Polypocephalus, and 2 morphologically distinct entities that may represent new genera. Aetomylaeus maculatus hosted as many as 6 species of Tylocephalum, 2 species of Polypocephalus, and 1 species of Lecanicephalum, all of which may also be new. Aetomylaeus nichofii sensu stricto hosted what appears to be an additional new species of Elicilacunosus, 1 new species of Polypocephalus, and up to 2 species belonging to yet an additional new genus. Aetomylaeus cf. nichofii 2 also hosted 2 species belonging to the latter additional new genus. In total, these specimens represent as many as 25 new species and 3 new genera beyond those formally described here. It is anticipated that additional collections of these host species will provide the material required to allow formal description of these taxa.

\section{DISCUSSION}

The 3 new genera erected here appreciably expand the spectrum of morphological variation seen in lecanicephalideans. Collicocephalus species demonstrate that the apical organ is not constrained to a configuration that is circular in cross-section; rather, it can be transversely extended. The enigmatic tandem series of depressions seen along the midline of the dorsal and ventral surfaces of the proglottids of Elicilacunosus species point to the existence of previously unknown attachment mechanisms, not merely in lecanicephalideans, but in eucestodes in general. The species of Rexapex provides a previously unseen variation on tentacle-like elaborations of the apical organ. 


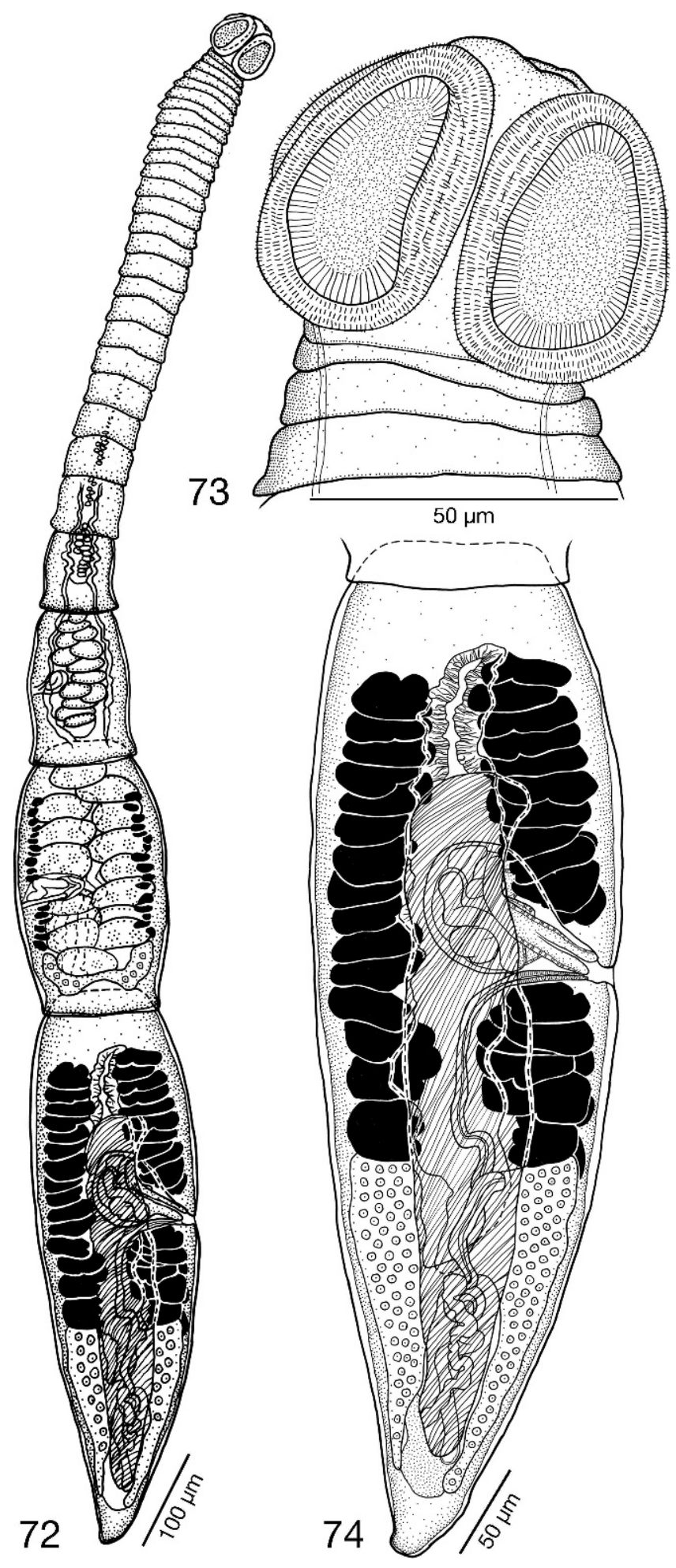

Figures 72-74. Line drawings of Aberrapex weipaensis n. sp. (72) Whole worm. (73) Scolex. (74) Mature terminal proglottid.

This work expands the confirmed hosts of lecanicephalideans to include Aetomylaeus. Although previously Shipley and Hornell (1906) described Tylocephalum dierama and Khambata and Bal (1953) described Discobothrium redacta and Discobothrium quadrisurculi, all from A. maculatus from Sri Lanka and/

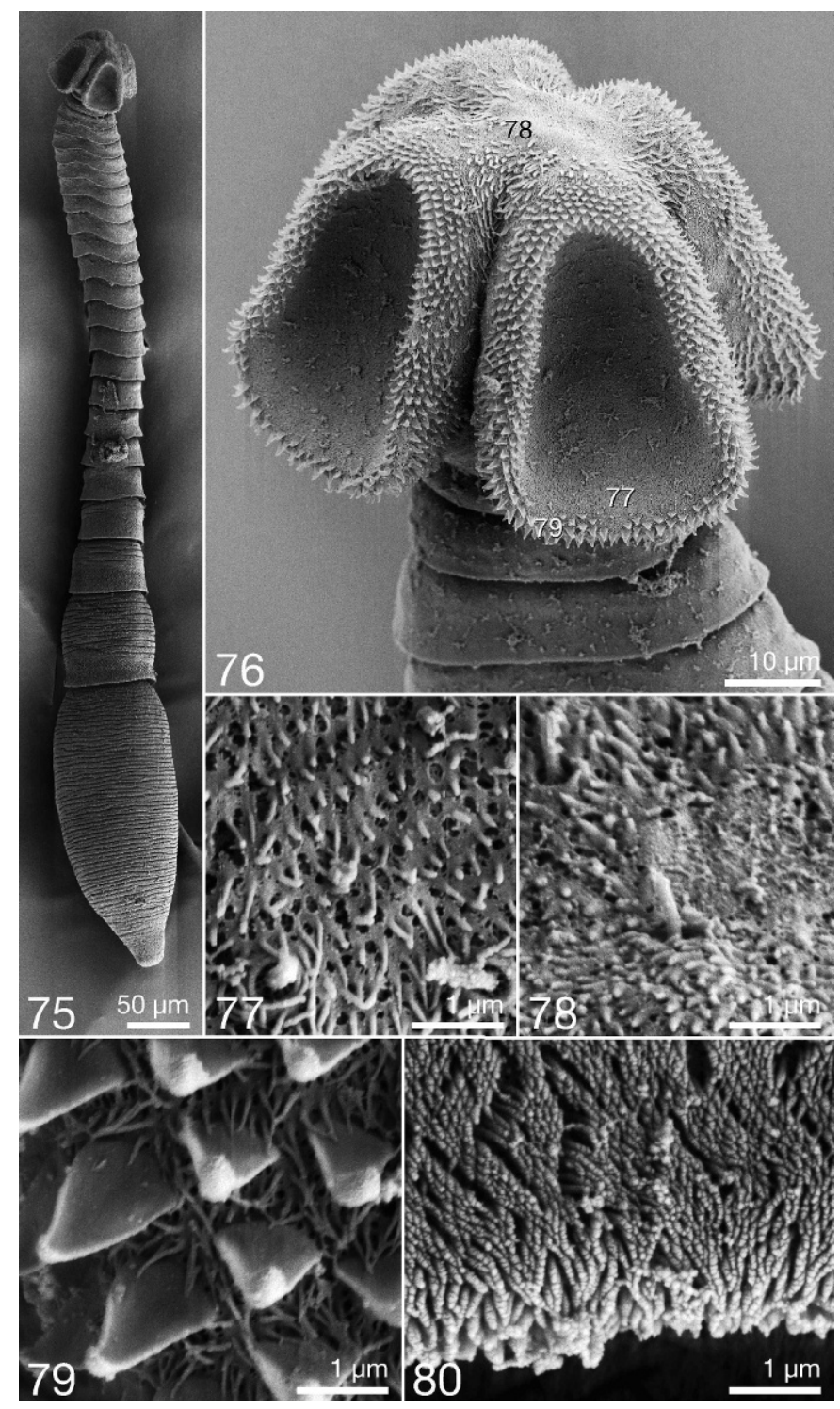

FIgURES 75-80. Scanning electron micrographs of Aberrapex weipaensis n. sp. (75) Whole worm. (76) Scolex. Small numbers indicate location of detail in Figures 77-79. (77) Distal acetabular surface with acicular and papilliform filitriches. (78) Apex of scolex proper with acicular filitriches. (79) Proximal acetabular surface with hastate spinitriches and acicular filitriches. (80) Subterminal proglottid with capilliform filitriches, becoming shorter toward posterior proglottid margin.

or India, Jensen (2005) found all 3 of these lecanicephalidean records to be problematic. In fact, she considered the former species to be a species inquirendum and the latter 2 species to be nomina nuda. As a consequence, the valid members of the lecanicephalidean fauna of Aetomylaeus are limited to the taxa reported herein. This myliobatiform genus is now known to be parasitized by 6 lecanicephalidean species representing 4 genera; all but Aberrapex are apparently unique to Aetomylaeus. With respect to these 4 genera, only Elicilacunosus was represented by more than a single species in Aetomylaeus. Each of the 6 lecanicephalidean species was found to parasitize only a single species of Aetomylaeus. The new species of Aberrapex expands the host range of this genus beyond the dasyatid Taeniura (see 
Jensen, 2006) and the myliobatid Myliobatis, to include a second myliobatid, Aetomylaeus.

The cestode faunas of the closely related $A$. nichofii sensu stricto and $A$. cf. nichofii 2 appear to differ in membership and diversity from one another, with the fauna of the former species exceeding that of the latter species in both respects. Prior to the present study, 6 species, all tetraphyllideans, had been reported from A. nichofii sensu stricto in Borneo and India (see Table I), while records from eagle rays in Australia, thus likely representing $A$. cf. nichofii 2, were restricted to the single tetraphyllidean Acanthobothrium rhynchobatidis Subhapradha, 1955, from Queensland, Australia (see Campbell and Beveridge, 2002). Based on the work conducted here, which involved necropsy of a relatively similar number of animals of each species, i.e., 10 of $A$. nichofii sensu stricto and 7 of $A$. cf. nichofii 2, 2 species of a new genus of lecanicephalidean have been formally added to the cestode fauna of $A$. nichofii sensu stricto. In addition, as noted above, this eagle ray species appears to host 4 lecanicephalidean species of 3 genera ( 1 new) that have not yet been formally described. In contrast, no new species of lecanicephalideans are described here from A. cf. nichofii 2, and, with respect to novel, undescribed species, it appears to host potentially only 2 . Of note, perhaps, is the fact that the spiral intestines of all 7 specimens of $A$. cf. nichofii 2 examined from northern Australia were each also parasitized by 1 to many large gnathostomid nematodes. However, such nematode infections were not seen in any of the 10 specimens of A. nichofii sensu stricto from Borneo.

Overall, the present study revealed remarkable diversity in the lecanicephalidean faunas of 4 species of Aetomylaeus from Borneo and northern Australia. The number of formally recognized lecanicephalidean genera has now increased from 14 to 17 , and the number of formally described species in the order has risen from 89 to 95 . These numbers do not include the potentially 25 additional new species and 3 novel genera not formally treated here. Among the 4 genera in its family, Aetomylaeus now ranks second only to Aetobatus in terms of the diversity of lecanicephalideans it hosts (see Table I). This work suggests that additional collections are likely to be particularly rewarding. Extrapolating from these results, we suspect that the remaining 2 species of eagle rays ( $A$. milvus and A. cf. nichofii 1 of Naylor et al. 2012), both known from the waters of the Middle East, will likely be found to host yet more novel taxa. Examination of additional specimens from Australia and Borneo of the 4 host species necropsied here should facilitate description of the potentially 25 new species and 3 new genera encountered in the present study but not yet described. Furthermore, examination of the faunas of specimens of these 4 eagle ray species from a wider spectrum of localities throughout their distributions may shed light on the generality of the faunal differences observed here. Finally, particularly valuable would be examination of the lecanicephalidean fauna of 1 , or both, of the species belonging to the fourth and final genus of myliobatid, Pteromylaeus.

\section{ACKNOWLEDGMENTS}

We are grateful to Loren Caira; Annie Lim (Fisheries Research Institute, Malaysia); Mabel Manjaji-Matsumoto (Universiti Malaysia, Borneo); Dharmadi (Research Centre for Capture Fisheries, Indonesia); Fahmi (Pusat Penelitian Oseanografi, Indonesia); Richard Mounsey (formerly, Darwin Fisheries, Australia); Gordon Yearsley (Commonwealth Scientific and Industrial Research Organization [CSIRO] Division of Marine Research, Tasmania); Gavin Naylor (College of Charleston), and Lyle Squire, Geoff Oke, and Julian Baggio (all of Cairns Marine, Australia), for their assistance with the collection of host specimens for this project. In addition, we thank Gavin Naylor for generating key host molecular data and William White and Peter Last for their assistance with host identifications. Our interpretation of the musculo-glandular structures on the proglottids of Elicilacunosus species was greatly informed by conversations with Alain de Chambrier (Museum d'Histoire Naturelle, Switzerland). This project was supported by National Science Foundation (NSF) Partnership in Enhancing Expertise in Taxonomy (PEET) 0103640 to J. N. Caira and C. S. Henry; NSF PEET 0118882 to J. N. Caira and T. R. Ruhnke; NSF Biotic Surveys and Inventories (BS\&I) 0103640 to J. N. Caira, K. Jensen, P. R. Last, J. D. Stevens, and G. J. P. Naylor; NSF BS\&I 0542846 and 0542941 to J. N. Caira, K. Jensen, P. R. Last, and G. J. P. Naylor; and NSF Planetary Biodiversity Inventories (PBI) 0818696 and 0818823 to J. N. Caira, K. Jensen, T. Littlewood, and J. Mariaux.

\section{LITERATURE CITED}

Alexander, C. G. 1953. Five new species of Acanthobothrium (Cestoda: Tetraphyllidea) from southern California rays. Journal of Parasitology 39: 481-486.

Beveridge, I. 1990. Taxonomic revision of Australian Eutetrarhynchidae Guiart (Cestoda: Trypanorhyncha). Invertebrate Taxonomy 4: 785845.

. 2008. Redescriptions of species of Tetrarhynchobothrium Diesing, 1850 and Didymorhynchus Beveridge \& Campbell, 1988 (Cestoda: Trypanorhyncha), with the description of Zygorhynchus borneensis $\mathrm{n}$. sp. Systematic Parasitology 69: 75-88.

, AND R. A. CAmpBell. 1987. Trimacracanthus gen. nov. (Cestoda: Trypanorhyncha: Eutetrarhynchidae), with redescriptions of $T$. aetobatidis (Robinson, 1959) comb. nov. and T. binuncus (Linton, 1909) comb. nov. Transactions of the Royal Society of South Australia 111: $163-171$.

, AND - 1988. A review of the Tetrarhynchobothriidae Dollfus, 1969 (Cestoda: Trypanorhyncha) with descriptions of two new genera, Didymorhynchus and Zygorhynchus. Systematic Parasitology 12: 3-29.

, AND - 1998. Re-examination of the trypanorhynch cestode collections of A. E. Shipley, J. Hornell and T. Southwell, with the erection of a new genus, Trygonicola, and redescriptions of seven species. Systematic Parasitology 39: 1-34.

, L. NeIFAR, AND L. Euzet. 2004. Eutetrarhynchid cestodes from Atlantic and Mediterranean elasmobranch fishes, with the description of two new species of Dollfusiella Campbell \& Beveridge, 1994 and redescriptions of Prochristianella papillifer (Poyarkoff, 1909) Dollfus, 1957 and Parachristianella trygonis Dollfus, 1946. Systematic Parasitology 59: 81-102.

Brooks, D. R., and M. A. Mayes. 1980. Cestodes in four species of euryhaline stingrays from Colombia. Proceedings of the Helminthological Society of Washington 47: 22-29.

,-- AND T. B. Thorson. 1981. Cestode parasites in Myliobatis goodie Garman (Myliobatiformes: Myliobatidae) from Rio de la Plata, Uruguay, with a summary of cestodes collected from South American elasmobranchs during 1975-1979. Proceedings of the Biological Society of Washington 93: 1239-1252.

— AND S. McCorquodale. 1995. Acanthobothrium nicoyaense n. $\mathrm{sp}$ (Eucestoda: Tetraphyllidea: Onchobothriidae) in Aetobatus narinari (Euphrasen) (Chondrichthyes: Myliobatiformes: Myliobatidae) from the Gulf of Nicoya, Costa Rica. Journal of Parasitology 81: 244-246.

Butler, S. A. 1987. Taxonomy of some tetraphyllidean cestodes from elasmobranch fishes. Australian Journal of Zoology 35: 343-371.

Campbell, R. A., And I. Beveridge. 2002. The genus Acanthobothrium (Cestoda: Tetraphyllidea: Onchobothriidae) parasitic in Australian elasmobranch fishes. Invertebrate Systematics 16: 237-344.

, AND - 2006. Two new species of Pseudochristianella Campbell \& Beveridge, 1990 (Cestoda: Trypanorhyncha) from elasmobranch fishes from the Gulf of California, Mexico. Parasite 13: $275-281$.

, AND - 2009. Oncomegas aetobatidis sp. nov. (Cestoda: Trypanorhyncha), a re-description of $O$. australiensis Toth, Campbell 
\& Schmidt, 1992 and new records of trypanorhynch cestodes from Australian elasmobranch fishes. Transactions of the Royal Society of South Australia 133: 18-29.

- AND J. G. CARVAJAL. 1979. Synonymy of the phyllobothriid genera Rhodobothrium Linton, 1889, Inermiphyllidium Riser, 1955, and Sphaerobothrium Euzet, 1959 (Cestoda: Tetraphyllidea). Proceedings of the Helminthological Society of Washington 46: 88-97.

Carvajal, J. 1977. Description of adult and larva of Caulobothrium myliobatidis sp. n. (Cestoda-Tetraphyllidea) from Chile. Journal of Parasitology 63: 99-103.

Carvajal, J. G., and J. G. Jeges. 1980. Cestodos parásitos de Myliobatis chilensis Philippi (Pisces: Myliobatidae), con la descripción de una nueva especie de Acanthobothrium. Anales del Centro de Ciencias del Mar y Limnologia 7: 51-56.

Chervy, L. 2009. Unified terminology for cestode microtriches: A proposal from the International Workshops on Cestode Systematics in 2002-2008. Folia Parasitologica 56: 199-230.

Cielocha, J. J., And K. Jensen. 2011. The description of a most unusual lecanicephalidean cestode, Hexacanalis folifer $\mathrm{n}$. sp. (Lecanicephalidea), from the zonetail butterfly ray, Gymnura zonura (Bleeker) (Rajiformes: Gymnuridae), with a redescription of the type species, H. abruptus (Southwell, 1911) Perrenoud 1931, and comments on the validity of the genus. Systematic Parasitology 79: 1-16.

Compagno, L. J. V. 1999. Checklist of living elasmobranchs. In Sharks, skates, and says: The biology of elasmobranch fishes, W. C. Hamlett (ed.). The Johns Hopkins University Press, Baltimore, Maryland, p. 471-498.

2005. Sharks, rays and chimaeras: The status of chondrichthyan fishes. In Global checklist of living chondrichthyan fishes, S. L. Fowler (ed.). International Union for the Conservation of Nature, Cambridge, U.K., p. 401-423.

Dailey, M. D., And D. R. Mudry. 1968. Two new species of Cestoda from California rays. Journal of Parasitology 54: 1141-1143.

de Chambrier, S., And A. De Chambrier. 2010. Two new genera and two new species of proteocephalidean tapeworms (Eucestoda) from reptiles and amphibians in Australia. Folia Parasitologica 57: 263279.

Diesing, K. M. 1863. Revision der Cephalocotyleen. Abtheilung: Paramecocotyleen. Sitzungsberichten der Akademie der Wissenschaften Wien, Mathematische-Naturwissenschaften Klasse Abtheilung I 48: 200-345.

Dollfus, R. P. 1969. De quelques cestodes Tétrarhynques (hétéracanthes et pécilacanthes) récoltés chez des poissons de la Méditerranée. Vie et Milieu 20: 491-542.

Euzet, L. 1951. Echinobothrium mathiasi n. sp. (Cestode Diphyllidea) parasite dune raie: Leiobatis aquila L. Bulletin de la Société Zoologique de France 76: 182-188.

. 1955. Quelques cestodes de Myliobatis aquila L. Recueil des Travaux des Laboratoires de Botanique, Géologie et Zoologie de la Faculté des Sciences de l'Université de Montpellier. Série Zoologique 1: $18-27$.

Heinz, M. L., AND M. D. DAILEy. 1974. The Trypanorhyncha (Cestoda) of elasmobranch fishes from southern California and northern Mexico. Proceedings of the Helminthological Society of Washington 41: 161169.

Ivanov, V. A., AND R. A. CAMPBell. 1998. Echinobothrium megacanthum sp. n. (Cestoda: Diphyllidea) from the eagle ray Myliobatis goodei (Chondrichthyes: Rajoidei) from the Patagonian shelf of Argentina. Folia Parasitologica 45: 225-229.

JAdhav, B. V., AND G. B. Shinde. 1987. Tylocephalum aurangabadensis sp. nov. (Cestoda: Lecanicephalidea) from a marine fish Aetobatis narinari from Arabian Sea. Indian Journal of Helminthology 39: $88-91$.

Jensen, K. 2001. Four new genera and five new species of lecanicephalideans (Cestoda: Lecanicephalidea) from elasmobranchs in the Gulf of California, Mexico. Journal of Parasitology 87: 845-861.

. 2005. Tapeworms of Elasmobranchs (Part 1). A monograph on the Lecanicephalidea (Platyhelminthes, Cestoda). Bulletin of the University of Nebraska State Museum 18: 241 p.

. 2006. A new species of Aberrapex Jensen, 2001 (Cestoda: Lecanicephalidea) from Taeniura lymma (Forsskal) (Myliobatiformes: Dasyatidae) from off Sabah, Malaysia. Systematic Parasitology 64: 117-123.
, AND J. N. CAIRA. 2006. The status of Rhoptrobothrium Shipley et Hornell, 1906 (Cestoda: Tetraphyllidea), with redescription of the type species, $R$. myliobatidis, and description of three new species from two species of Aetomylaeus (Myliobatiformes: Myliobatidae) from Malaysian Borneo. Folia Parasitologica 53: 189-207.

—_, P. Nikolov, and J. N. Caira. 2011. A new genus and two new species of Anteroporidae (Cestoda: Lecanicephalidea) from the darkspotted numbfish, Narcine maculata (Torpediniformes: Narcinidae), off Malaysian Borneo. Folia Parasitologica 58: 95-107.

Khambata, F. S., And D. V. Bal. 1953. Two new species of the genus Discobothrium (Cestoda) from the Marine Fishes of Bombay. Proceedings of the Fortieth Indian Science Congress, Lucknow, India, p. 192.

Last, P. R., And J. D. Stevens. 2009. Sharks and rays of Australia, 2nd ed. CSIRO, Canberra, Australia, 513 p.

, W. T. White, J. N. Caira, Dharmadi, Fahmi, K. Jensen, A. P. K. Lim, B. M. Manjaji-Matsumoto, G. J. P. Naylor, J. J. Pogonoski, ET AL. 2010. Sharks and rays of Borneo. CSIRO Publishing, Canberra, Australia, 298 p.

Linton, E. 1890. Notes on Entozoa of marine fishes of New England, with descriptions of several new species. Part II. Report of United States Commissioner of Fisheries (1887), Washington, D.C., 15: 718-899.

. 1916. Notes on two cestodes from the spotted sting-ray. Journal of Parasitology 3: 34-37.

MacCallum, G. A. 1917. Some new forms of parasitic worms. Zoopathologica 1: 43-75.

- 1921. Studies in helminthology. Part 1. Trematodes. Part 2. Cestodes. Part 3. Nematodes. Zoopathologica. Scientific Contributions of the New York Zoological Society on the Diseases of Animals 1: $135-284$.

Marques, F., D. R. Brooks, and R. Barriga. 1997. Six species of Acanthobothrium (Eucestoda: Tetraphyllidea) in stingrays (Chondrichthyes: Rajiformes: Myliobatoidei) from Ecuador. Journal of Parasitology 83: 475-484.

Mayes, M. A., AND D. R. Brooks. 1981. Cestode parasites of some Venezuelan stingrays. Proceedings of the Biological Society of Washington 93: 1230-1238.

Mohekar, A. D., H. K. Bhagwan, and C. J. Hiware. 2002. Biodiversity of cestode parasites parasitizing piscian host from Elasmobranchii collected along west coast of Maharashtra. Uttar Pradesh Journal of Zoology 22: 97-98.

Naylor, G. J. P., J. N. Caira, K. Jensen, K. A. M. Rosana, W. T. White, AND P. R. LAST. 2012. A DNA sequence based approach to the identification of shark and ray species and its implications for global elasmobranch diversity and parasitology. Bulletin of the American Museum of Natural History. (In press.)

Palm, H. W. 2004. The Trypanorhyncha Diesing, 1863. PKSPL-IPB Press, Bogor, Indonesia, $710 \mathrm{p}$.

Pramanik, P. B., And B. Manna. 2005. Cephalobothrium gogadevensis new species (Cestoidea: Lecanicephalidae) from Rhinobatus granulatus Cuv., 1829 from Bay of Bengal at Digha Coast, India. Journal of Natural History 1: 38-43.

$\longrightarrow$ AND $\longrightarrow$ 2006. Polypocephalus himanshui n. sp. (Cestoda: Lecanicephalidae) from Rhynchobatus djeddensis Forsskål, 1775 from Bay of Bengal at Digha Coast, West Bengal, India. Indian Journal of Animal Health 45: 125-138.

$\longrightarrow$, AND - 2007. Six new species of the genus Tylocephalum Linton, 1890 (Cestoida: Lecanicephalidea) in cartilagenous fishes from Bay of Bengal at Digha coastal waters, West Bengal, India. Journal of Natural History (India) 3: 12-33.

RaO, V. 1977. Acanthobothrium hanumantharaoi sp. n. (Cestoda: Tetraphyllidea, Onchobothriidae) from the Niehof's eagle ray, Myliobatis nieuhofii (Bloch and Schneider) of Waltair Coast, Bay of Bengal. Rivista di Parassitologia 38: 277-283.

Riser, N. W. 1955. Studies on cestode parasites of sharks and skates. Journal of the Tennessee Academy of Science 30: 265-311.

Robinson, E. S. 1959. Some new cestodes from New Zealand marine fishes. Transactions of the Royal Society of New Zealand 86: 381-392.

Sarwade, D. V., G. B. Shinde, E. S. Pawar, and M. A. Mahajan. 1995. On a new species of the genus Myliobatibothrium Mohekar and Shinde from Myliobatis nieullofii [sic] at Aurangabad, M. S. India, Muller and Henle. Rivista di Parassitologia 12: 87-89. 
Sheehan, D. C., and B. B. Hrapchak. 1987. Theory and practice of histotechnology, 2nd ed. Battelle Memorial Institute, Columbus, Ohio, $481 \mathrm{p}$.

Shinde, G. B., B. B. Dhule, and D. H. Jadhav. 1991. Polypocephalus bombayensis sp. nov. (Cestoda: Lecanicephalidae) from a marine fish Aetobatus flagellum at Kakinada (A. P.), India. Indian Journal of Helminthology 43: 77-79.

, AND A. D. Mohekar. 1983. Myliobatibothrium alii gen. et sp. $\mathrm{n}$. (Cestoda: Tetraphyllidea) from ray, Myliobatis nieuhofii (Muller and Henle). Rivista di Parassitologia. 44: 247-251.

Shipley, A. E. 1900. A description of the Entozoa collected by Dr. Willey during his sojourn in the western Pacific. Zoological Results based on material from New Britain, New Guinea, Loyalty Islands and elsewhere, collected during the years 1895, 1896, and 1897, by Arthur Willey, 5: 1-42.

- 1909. Anthobothrium crispum. Zoologischer Anzeiger 34: 641 , AND J. HoRnell. 1905. Further report on parasites found in connection with the pearl oyster fishery at Ceylon. In Report to the Government of Ceylon on the Pearl Oyster Fisheries of the Gulf of Manaar (Herdman), Part 3. The Royal Society, London, U.K., p. 49-56. , AND 1 . 1906. Report on the cestode and nematode parasites from the marine fishes of Ceylon. In Report to the Government of Ceylon on the Pearl Oyster Fisheries of the Gulf of Manaar (Herdman), Part 5. The Royal Society, London, U.K., p. 43-96.

Southwell, T. 1911. Description of nine new species of cestode parasites, including two new genera from marine fishes of Ceylon. Ceylon Marine Biological Report 1: 216-225.

- 1925. A monograph on the Tetraphyllidea with notes on related cestodes. Memoirs of the Liverpool School of Tropical Medicine (New Series) 2: 1-368.

Srivastav, A. K., S. Lohia, and N. Mathur. 1995. Acanthobothrium myliomaculata sp. nov. (Onchobothriidae, Cestoda) from the
Myliobates maculata from Madras (India). Flora and Fauna 1: $43-$ 45 .

Toth, L. M., R. A. Campbell, and G. D. Schmidt. 1992. A revision of Oncomegas Dollfus, 1929 (Cestoda: Trypanorhyncha: Eutetrarhynchidae), the description of two new species and comments on its classification. Systematic Parasitology 22: 167-187.

Tyler, G. A., And J. N. Caira. 1999. Two new species of Echinobothrium (Cestoidea: Diphyllidea) from myliobatiform elasmobranchs in the Gulf of California, Mexico. Journal of Parasitology 85: 327-335.

Vankara, A. P., C. Vijayalakshmi, and J. Vijayalakshmi. 2006. Description of a new species, Polypocephalus kuhlii n. sp. (Lecanicephalidea: Polypocephalidae) from Dasyatis kuhlii (Müller \& Henle) from Visakhapatnam coast, Bay of Bengal, India. Journal of Parasitology and Applied Animal Biology 15: 63-68.

- $\longrightarrow$ AND 2007. Polypocephalus visakhapatnamensis $\mathrm{sp}$ nov. (Lecanicephalidea: Polypocephalidae) from Himantura uarnak (Forsskål) and Dasyatis (Amphotistius) zugei (Müller \& Henle) from Visakhapatnam coast. Journal of Parasitic Diseases 31: 152-154.

WANKHEDE, H. 2003. On a new species of the genus Hexacanalis Perrenoud (1931) from the spiral valve of Dicerobatis erregoodoo. Journal of Parasitic Diseases 27: 124-125.

White, W. T., P. R. Last, G. J. P. Naylor, K. Jensen, and J. N. Caira. 2010. Clarification of Aetobatus ocellatus (Kuhl, 1823) as a valid species, and a comparison with Aetobatus narinari (Euphrasen, 1790) (Rajiformes: Myliobatidae). In Descriptions of new sharks and rays from Borneo, P. R. Last, W. T. White, and J. J. Pogonoski (eds.) CSIRO Marine and Atmospheric Research Paper 032, Hobart, Australia, p. 141-164.

Yamaguti, S. 1934. Studies on the helminth fauna of Japan. Part 4. Cestodes of fishes. Japanese Journal of Zoology 6: 1-112.

Zaidi, D. A., And D. Khan. 1976. Cestodes of fishes from Pakistan. Biologia 22: 157-179. 